\title{
Black Americans and Interracial Marriage: A Focus on Black Women
}

\author{
Amadu Jacky Kaba \\ Department of Sociology, Anthropology and Social Work, Seton Hall University, South Orange, NJ, USA \\ Email: Amadu.Kaba@shu.edu
}

Received May $20^{\text {th }}$, 2012; revised June $18^{\text {th }}$, 2012; accepted June $27^{\text {th }}$, 2012

\begin{abstract}
This paper claims that although there has been a significant increase in the number of scholarly publications on interracial marriages in the United States in recent decades, most of these publications tend to focus on the small but visible increase in marriages, co-habitations and dating; how Whites or European Gentile Americans are gradually becoming accepting of these relationships; the factors that are causing non-Blacks to "reject" Blacks; and specifically factors that are causing White men and other non-Black men to "reject" Black women. As a result, the paper attempts to contribute to this topic by focusing on an important phenomenon - that it could actually be Black women who are turning down non-Black men. The paper presents eight factors that may be causing Black women to turn down interracial romantic relationship requests from non-Black men.
\end{abstract}

Keywords: Black American Women; Interracial Marriage; Economics; Education Levels; History; Gender and Race

\section{Introduction}

There has been a significant increase in the number of scholarly publications on interracial marriages in the United States in recent decades. These publications tend to focus on selected areas. One such area is the relatively small but visible increase in the number of interracial marriages, co-habitations, and dating in the post Civil Rights and Women's Rights era. Another area that has been examined is the gradual acceptance in recent decades of these relationships by Whites or Gentile European Americans, especially acceptance of Asians, Hispanics and other non-Black human beings. A number of these studies have also focused on the factors that are causing non-Blacks to reject Blacks as potential marriage or dating partners, and specifically factors that are causing White Gentile European American men, certain Black men and other non-Black men to reject Black women (Banks, 2011; Blau et al., 1988; Cready \& Saenz, 1997; Crowder \& Tolnay, 2000; Huges, 2003a, 2003b; Kaba, 2011a; Kalmijn, 1993, 1998; Mare, 1991; Model \& Fisher, 2001; Porter \& Bronzaft, 1995; Tucker \& Mitchell-Kernan, 1990; Qian, 1997; Walsh, 2012; Wong, 2003).

There has been very little or no attention paid to the fact that Black women in the United States might actually be the ones rejecting or turning down romantic relationship requests from Whites or non-Black men. This is an important neglected phenomenon that needs scholarly attention. As a result, this article attempts to contribute to this topic by focusing on this important phenomenon-that it is actually Black women who are turning down non-Black men's requests for interracial romantic relationships.

This article examines the factors that are causing Black women to turn down interracial romantic relationship requests from non-Black men, especially White Gentile European American men. The article begins by presenting various statistics illustrating the trends in interracial romantic relationships in recent decades. Next, the article presents information focusing on the opinions of non-Blacks as to why so few of them "prefer" interracial romantic relationships such as marriage with Black people, and also more specifically, the reasons that have been presented as to why White Gentile European American men, other non-Black men, such as Asians and Hispanics, and Black men who prefer non-Black women, all do not get involved in marriage with Black women in the United States. Finally, the article makes the claim that it is actually Black women who turn down or reject non-Black men's request for romantic relationships and goes on to present many factors responsible for this phenomenon.

\section{Numbers and Percentages of Black Men and Black Women Involved in Interracial Romantic Unions}

In 1980 , there were 167,000 married Black/White couples and 34,000 marriages involving a Black person and another race in the United States. Of the 167,000 Black/White-married couples, 122,000 (73\%) had a Black husband and a White wife, and 45,000 (27\%) had a White husband and a Black wife. In 1990, there were 211,000 Black/White married couples in the United States and 33,000 married couples involving a Black person and another race. Out of the 211,000 Black/White-married couples, 150,000 (71\%) had a Black husband and White wife and 61,000 (29\%) had a White husband and a Black wife (US Census Bureau, 1999).

As of March 2000, there were 363,000 Black/White married couples and 88,000 Black/White unmarried couples, adding up to a total of 451,000 Black/White couples. During that same time, there were 25,000 Black/Asian and Pacific Islander married couples and 9000 Black/Asian and Pacific Islander (API) unmarried couples (Fields \& Casper, 2001: p. 15).

In March 2000, there were 268,000 Black/White married 
couples with a Black husband and a White wife, and 95,000 married couples with a Black wife and a White husband. There were 25,000 Black/Asian and Pacific Islander married couples with a Black husband and an Asian and Pacific Islander (API) wife. There were 12,000 Black/API married couples with a Black husband and an American Indian and Alaskan Native (AIAN) wife. There were 13,000 married couples with American Indian and Alaskan Native (AIAN) husbands and Black wives (Fields and Casper, 2001).

In a further breakdown using different race and ethnic classifications, as of March 2000, there were 41,000 marriages with Hispanic husbands and Black wives. There were 72,000 marriages with a Black husband and a Hispanic wife. There were 80,000 marriages with a White husband and a Black wife. There were 227,000 marriages with a Black husband and a White wife. There were 35,000 marriages with a Black husband and a wife belonging to a group classified as other. There were 11,000 marriages with a husband classified as other and the wife as Black (Fields and Casper, 2001).

In March 2000, there were 11,000 unmarried couples with a White male and a Black female. There were 69,000 unmarried couples with Black males and White females. There were 12,000 unmarried couples with Black males and Hispanic females. There were 5000 unmarried couples with Black males and females classified as other. There were 3000 unmarried couples with Hispanic males and Black females. There were 6000 unmarried couples with males classified as other and Black females (Fields and Casper, 2001).

In 2010, there were 2,413,000 interracial married couples in the United States. Of that total, 1,723,000 (71.4\%) were between Whites and people in other racial groups. In 2010, there were 558,000 Black-White married couples in the United States, with 390,000 (69.9\%) representing Black husbands and White wives and 168,000 (30.1\%) representing White husbands and Black wives. In 2010, there were 132,000 marriages between Blacks and people in another race who were not White ${ }^{1}$.

Pertaining to interracial dating, Ellis Cose cited an unpublished report claiming that: "In a survey of residents of 21 cities, Tucker \& Co. found that 78 percent of black men (average age: 32) had dated interracially at least once, as had 53 percent of black women (average age: 34)” (Cose, 2003: p. 46). It is reported that the percentage of adult Blacks who have dated at least one White American in their lifetime was 43\%, and $17 \%$ for Whites who have dated at least one Black in their lifetime (High Beam Research, 2003).

The above statistics illustrate that the overall Black-White and Black-Other races marriages or couples are not as large relative to the total number of Black people in the United States, which was 40 million in 2010, while the non-Hispanic White population was almost 200 million. The statistics above also show that although there are more marriage age Black women than Black men in the United States, there are more Black men involved in interracial romantic relationships.

Kaba (2011a) presents several factors that have been cited as responsible for the visible increase in the number of interracial marriages in general or co-habitations in the United States in recent decades. Among the factors cited are: Increase in tolerance in the United States, Assimilation, Socioeconomic/Status

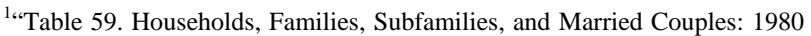
to 2010," 2012. Statistical Abstract of the United States. United States Census Bureau. Retrieved on March 22, 2012 from:

http://www.census.gov/compendia/statab/2012/tables/12s0059.pdf
Exchange Theory and Education, Geographic Location, Military, and Age (pp. 123-124). However, all of these factors apply less to Blacks, especially Black women. Why then are so few Blacks involved in these relationships? For example, Kaba (2011a) cites the following factors that have contributed to very few Blacks married to Whites in the United States: Family and Racial Community Acceptance of Interracial Romantic Relationships, Group Size and Third Party Influence, Marginalization and Stigma, the History of Forced Sexual Relations on Blacks by Whites in the United States, Politics/Laws Preventing Blacks from Interracial Marriages, and Concern about the Potential Transfer of Wealth in Interracial Marriages (pp. 124-127).

\section{Why Do So Few Whites and Non-Blacks Marry Blacks in the United States?}

Although the proportion of Whites who support interracial marriages or unions has increased in the past several decades, as the data above show the actual marriage numbers are very small, especially with over 42 million Blacks and almost 200 million non-Hispanic Whites in the United States by 2011. A 1958 poll found that $96 \%$ of Whites disapproved of marriages between Blacks and Whites. In 1997, 77\% of them approved (Kaba, 2011a: p. 124). By 2011, 84\% of White Americans approved Black-White marriages (Kaba, 2011b: p. 168). However, an increase in approval of Black-White romantic relationships or marriages does not actually mean that substantial rates of Whites and other non-Blacks are in such relationships with Blacks. Moreover, dating is a lot different from being in a committed relationship. What has remained constant in the past 400 years is that actual sexual relations between the two groups have never stopped. In an article that reviews the book Thomas Jefferson and Sally Hemmings; An American Controversy, by Annette Gordon-Reed (1998), Camp (2000) writes that:

\begin{abstract}
"Miscegenation in America is often a spectacular story, even when neither participant is famous: black/white liaisons in the United States are imbued with the love and hate, attraction and repulsion, desire and fear that exists across the color line. At the same time, though, miscegenation is a commonplace. Black and white couples, families, affairs, sexual predations share the banalities of all sexual and intimate relations. Most important, they are far from new and their status as scandal or surprise has not been static” (p. 279).
\end{abstract}

Let us examine some examples of these contradictions.

In a study in which 60 individuals living in Southern California and involved in Black-White marriages, Walsh (2012) tells the story of a Black Husband-White wife: that when they started dating her “... parents were thrilled when we started seeing each other. In 1950s having your daughter going with a Neeg-roe (pro-nounced deliberately in two emphatic syllables) was like an endorsement for them, "Look everyone; we raised her with the right values. It was a validation for them. Nawt so-oo happy when we decided to get married" (p. 77). McClintock's (2010) study of interracial romantic relationships among undergraduate students at Stanford University presents this example of a Black male student: "A Black male who described himself as having grown up in a poor minority neighborhood felt that he was an object of sexual novelty for White women. He said that the women he hooks up with 'tend 
to be White... and upper-class. And they're, they're 'slumming'... they're 'slumming'! ... There's a class divide here that no one talks about, but it really comes out in dating, because, like, girls who will really hook up with me would never date me", (p. 67).

According to a 2001 Washington Post survey, about 4 in 10 Americans reported to have dated someone of another race and a companion survey found that more than two-thirds of those relationships were "serious romantic relationships." According to the Washington Post survey, 70\% of Asian men and 63\% of Asian women have dated someone of another race. Sixty-two percent of Black men and $47 \%$ of Black women reported to have dated someone of another race. Fifty-five percent of Latino men and $36 \%$ of Latina women reported to have dated someone of another race. Forty-four percent of White men and $35 \%$ of White women reported to have dated someone of another race (Fears \& Deane, 2001).

In a poll of people in the United States in 2001, the following question was asked: "Considering everything, do you think it's better for people to marry someone of their own race, better to marry someone of a different race, or doesn't make any difference?" Seventy-seven percent of Blacks answered that it does not make any difference. Twenty-one percent of Blacks answered that they preferred for people to marry their own race. Fifty-three percent of Whites answered that it makes no difference to marry another race and $46 \%$ answered that they preferred for people to marry within their own race. Sixty-eight percent of Hispanics answered that it makes no difference to marry another race and $29 \%$ answered that they preferred for people to marry within their own race. Sixty-seven percent of Asians answered that it makes no difference to marry another race and $30 \%$ answered that they preferred for people to marry within their own race (Fears \& Deane, 2001).

Age seems to make a significant difference in the perception of interracial dating and marriage, with younger Americans showing less opposition to such relationships. Among those who answered that it is "better to marry your own race," $68 \%$ were 65 years or over, $52 \%$ were 50 to 64 years, $34 \%$ were 30 to 49 years and $17 \%$ were 18 to 29 years (Fears \& Deane, 2001). Age has been cited for the increase in cross-cultural romantic relationships. Younger individuals are said to be more open to such relationships (Model \& Fisher 2001; Joyner \& Kao 2000; Wilensky, 2002; McWhorter, 2003: pp. 70-71). According to Model and Fisher (2001), “... younger people are expected to exhibit higher rates because the passage of time is associated with increasing tolerance for exogamy" (p. 179). Moreover, America's schools and colleges are more diverse than ever before and the teachers and professors are teaching students not to judge people based on their ethnic or racial backgrounds, rather they should judge people based on their character. Joyner and Kao (2000) point out that Black male students on average tend to attend schools that are $44 \%$ Black, while White male students attend schools that are $73 \%$ White. Joyner and Kao add that “... 10\% of white students, $20 \%$ of black, $40 \%$ of Hispanic and Asian students, and the vast majority of Native American youth report an interracial friendship" (p. 813).

Due to increased interactions among youths of all races and ethnicities, and the increase of television programs and Hollywood movies depicting interracial activities and relationships, most young people today of any race tend to be tolerant of members of other ethnic or racial groups. McWhorter (2003) notes that, “... increasingly movies for teens depict a world where, with no particular attention called to it, blacks and whites coexist in easy harmony” (pp. 70-71). An investigation of the "... the ratio of both-black marriages to mixed-black marriages in 1990” shows that:

"For those over 65 years of age, the ratio is over $6: 1$, for those under 35 years old it drops to $3: 2$, and for those under 25 it approaches 1:1. In 1990, 84\% of all married black people over the age of 65 were in both-black marriages, but only $53 \%$ of married blacks under 25 were. Thus, a large part of the apparent education and income disparity might be explained by accounting for the older population, who married almost exclusively within their race and, due to segregation and discrimination, were denied many of the educational and income opportunities that younger people have” (The Statistical Assessment Service, 1997).

When the question "How do you think you would react if a member of your family told you they were going to marry [Black, White, Latino and Asian]...?” was asked, 86\% of Black respondents answered that it would be fine with them if a member of their family married a White, 86\% supported marrying an Asian, and 85\% supported marrying a Latino. For Latino respondents, $86 \%$ answered that they would be fine if a member of their family were to marry a White, 79\% supported marrying an Asian, and 74\% supported marrying a Black person. For Asian respondents, $77 \%$ answered that it would be fine with them if a member of their family were to marry a White, $71 \%$ supported marrying a Latino, and $66 \%$ supported marrying a Black person. For Whites respondents, 66\% answered that it would be fine with them if a member of their family were to marry a Latino, 65\% supported marrying an Asian, and 55\% supported marrying a Black person (Fears \& Deane, 2001).

The figures above show that in addition to Whites, significant proportions of Asians and Hispanics tend not to support family members who marry Blacks, partly due to negative views of Blacks in the society (Oliver \& Wong, 2003: p. 569).

It is pointed out that: "blacks stand out uniquely among the array of American ethnic and racial groups in the degree to which marriage remains within the group” (Kennedy, 2002). The late Black American scholar and Statesman W. E. B. DuBois (1965) writes of his experience as a young boy pertaining to how White Americans teach their children at very young ages to hate people of Black African descent during that era:

"It is in the early days of rollicking boyhood that the revelation first bursts upon one, all in a day, as it were. I remember well when the shadow swept across me. I was a little thing, away up in the hills of New England, where the dark Housatonic winds between Hoosac and Taghkanic to the sea. In a wee wooden schoolhouse, something put it into the boys' and girls' heads to buy gorgeous visiting-cards-ten cents a package-and exchange. The exchange was merry, till one girl, a tall newcomer, refused my card-refused it peremptorily, with a glance. Then it dawned upon me with a certain suddenness that I was different from the others; or like, mayhap, in heart and life and longing, but shut out from their world by a vast veil. I had thereafter no desire to tear down that veil, to creep through; I held all beyond it in common contempt, and lived above it in a region of blue sky and great wandering shadows. That sky was bluest when I could beat my mates 
at examination-time, or beat them at a foot-race, or even beat their stringy heads. Alas, with the years all this fine contempt began to fade; for the worlds I longed for, and all their dazzling opportunities, were theirs, not mine. But they should not keep these prizes, I said; some, all, I would wrest from them” (p. 214; also see Granger, 2002).

In a study by Robnett and Feliciano (2011) of heterosexual individuals in the United States who are seeking romantic partners on the internet by posting their profiles, $96.69 \%$ of White men (444 sample size), $81.5 \%$ of Latino men (400 sample size), and $94.56 \%$ of Asian men (423 sample size) excluded Black women from their search for partners; $91.62 \%$ of White women (489 sample size); $76.4 \%$ of Latina women (504 sample size); and $94.44 \%$ of Asian women (468 sample size) also excluded Black men from their search for partners. Also, 29.23\% of White men, $15.5 \%$ of Latino men, $20.8 \%$ of Asian men, $65.44 \%$ of White women, $16.5 \%$ of Latina women, $6 \%$ of Asian women said they prefer their own race (p. 815). Robnett and Feliciano (2011) add that:

"While limited research has focused on the primary structural assimilation of Middle Easterners or East Indians, recent studies argue that similar to the inclusion of European immigrant groups, the boundaries of 'whiteness' are extending to include Latinos and Asians, but remain closed to blacks... Evidence for this thesis is found in both the greater acceptance by whites of Latinos and Asians than blacks, and also the greater acceptance of whites than blacks by Latinos and Asians. For example, whites are more accepting of their children marrying Asians and Latinos than blacks... and, in turn, intermarriage between whites and Latinos or Asians is much more common than black-white intermarriage... Moreover, Asians and Latinos rate whites and one another more favorably than blacks... and both groups prefer to live with whites over blacks...” (p. 809).

According to Perry and Sutton (2008): "Although most inter-ethnic marriages include a white person, white people are the least likely to be married to someone outside their ethnic group-only 1 percent of white men or women had done so" (Quoted in the Introduction section of article).

Authors and scholars have pointed out that Black Americans are more accepting of interracial romantic relationships. Leslie (1996) points to observations that White American families were less accepting of interracial romantic relationships than Black American families. The reason for this was that Black mothers play a primary role within their families and that they tend to be more open and to relate to Whites than White men, who play a key role within their families, but tend to be less likely to accept people from outside racial groups. Leslie (1996) also adds that African American families tend to accept White in-laws because of an Africentric heritage, which normally “... emphasize the inclusion of blood grandchildren... close blood ties among African American families are related more to this

\footnotetext{
${ }^{2}$ Kanazawa, Satoshi. 2011, May 15. "Why are black women rated physically less attractive than other women, but black men are rated better looking than other men," Psychology Today. Republished in Loveys, K., and Fernandez, C. 2011, May 18. "Black women are less attractive than others": Controversial LSE psychologist sparks backlash with his "scientific" findings," Daily Mail. Retrieved on May 5, 2012 from: http://www.dailymail.co.uk/news/article-1388313/LSE-psychologist-Satosh i-Kanazawa-claims-black-women-attractive.html
}

Africentric concept on immortality and strong family traditions than to clannishness" (pp. 530-531). Kalmijn (1993) notes that among the reasons why White women marry Black men is that "... white women are generally more tolerant towards blacks than white men are” (p. 140), but also points to a 1990 US Census survey that shows a lower proportion of White men than White women who support laws banning Black-White marriages: “... 24\% of white women favored these laws, while only $17.4 \%$ of white men did so (N754). When we just focus on high school graduates, the difference is of a similar magnitude, $21.5 \%$ for women and $16.2 \%$ for men” (p. 140).

The persistent unnecessary negative image of Black Americans in the society in the past centuries is a big part of this phenomenon. For example, Sivanarayanan (2005) points to research that claims that: “... the long history of photographic representations of black women into three broad groups: the naked female of the National Geographic or the 'Jezebel' aesthetic" (the one I was most familiar with), the sexless "mammy' aesthetic," and the dignified figure of the black female that is part of the "noble savage' aesthetic" (p. 1109).

There is the perception in the society of Black Americans, especially Black women that they are angry, thereby causing non-Blacks not to desire them for romantic relationships, including marriage. According to Carter et al. (2008):

"The experience and expression of anger in Black populations has been widely documented... and some scholars discuss anger and its manifestations as a response to racism-related experiences... Although some scholars have recognized the centrality of anger and the racialcultural double-edged nature of its expression for Black Americans, these scholars have argued that the stereotypical social view of Blacks as being an angry people may also contribute to counselors' and mental health professionals' tendency to overpathologize them...” (p. 102).

Morgan and Bennett (2006) challenge the claim of a scholar with “... the stereotypes about Black women as angry and bitter, which have been embedded in contemporary discourses about Black male/White female relationships.” and explain “... the stereotype of the 'Angry Black Woman' as cultural ideology rather than social or psychological reality, an ideology that serves to silence and dehumanize Black women by blaming them for experiences of racist sexism that affect them in personal and political ways” (p. 486; also see Harris-Perry, 2011; Toldson \& Marks, 2011).

In an article published in Psychology Today entitled "Why are Black Women Rated Physically Less Attractive Than Other Women, But Black Men are Rated Better Looking Than Other Men”, Kanazawa (2011) used data of a survey of adolescents on the attractiveness of females in the United States: 3.716 for White females; 3.567 for Black females; 3.675 for Asian females; and 3.657 for Native American females, and used that very tiny difference to claim that Black females are unattractive and that is the reason why non-Black men do not seek romantic relationships with them: "The only thing I can think of that might potentially explain the lower average level of physical attractiveness among black women is testosterone. Africans on average have higher levels of testosterone than other races... women with higher levels of testosterone have more masculine features and are therefore less physically attractive."2 Simmons (2003) writes that: "Ongoing sexual stigmatization made it very risky for African American women to claim sexual freedom or pleasure” (p. 170). 
One can present a strong argument that among all of the racial and cultural groups and sub-groups in the United States, Black American women or Black females are actually the group that is least angry. For example, although Black females in the United States are almost 22 million, Kaba (2008a) points out that in June 2006 there were only 68,800 Black females in jails and prisons in the United States (p. 330). If one were to just stop and think about this: no other group has suffered as Black females in the history of the United States. This means that they have all of the excuses to commit crimes and yet only 68,800 of them were in jails and prisons in June 2006. Only people without anger and with a lot of discipline, calm temperament and deep faith can be so extraordinary. Is it not anger against Black females that is causing so many unnecessary deaths of Black baby girls, the exclusion of Black women from top leadership positions in the country, even though they and European American women are the most native to the United States apart from Native Americans, or the ongoing gender and racial prejudices targeted at them? (Kaba, 2012a, 2011c; Philpot \& Walton Jr., 2007; Washington, 2006). It takes deep anger to exhibit prejudice and racism against others. Let us now examine literature on Black men who do not date or marry Black women in the United States.

\section{Black Men Who Do Not Date or Marry Black Women}

Pertaining to the group of Black males who only date or marry White females or other non-Black females, Jeter (1982) points to a study of 40 Black-White couples in four states during the period from 1970 to 1974, in which the couples had dated for an average of 16 months before they got married. The couples entered their marriages at the average age of 24 , and they had been married for five years after the study (an in-depth taped interviews with the couples) was conducted. According to the study, for 28 Black male-White female couples, and three White male-Black female couples, love and compatibility were cited as motive for their union. Three other Black male-White female couples cited “... love and compatibility and added that the white female was less domineering, pregnant, or perceived as a status symbol." For two Black male-White female couples in the study, they did not cite love and compatibility, but for one of the couples, “... the husband wanted a less domineering white women and to rebel against tradition. His wife was attracted to black men.” Finally, for the second couple, “... the husband felt he increased his social status. His spouse perceived herself as an outcast with white people" (p. 105).

Walsh's (2012) study presents this account of a Black Husband-White wife on this claim:

"Marilyn Waters, 38, divorced her black husband after 18 years". Marilyn not only relies on an image of "nice white girls" to explain her lack of assertiveness, she implicates me in her circle of white femininity with use of "us" and "we" to describe the hyper-politeness associated with "rarified southern white la-dies"... She uses her innocence associated with whiteness and femininity to excuse her inability to take a stand. Then, Marilyn engages in essentialist discourse while noting, "they hear everything, they see everything”. While it is unclear whether she attributeing this extra sensory perception only to black men or to all blacks, it is clear that she draws upon essential think- ing about both gender and race in her description of her ex-husband's alleged omnipotence. When she invokes the metaphor of "being eaten up alive", Marilyn relies on a familiar cultural representation, with a long history, which portrays black men, in general, and black sexuality, specifically, as predatory and all-consuming” (p. 78).

According to Morgan and Bennett (2006):

"The reversal of the discourse about interracial relationships from the historical construct in which White men sexually dominated Black women to the contemporary one in which Black men sexually commune with White women has significant consequences for constructions of all the racial groups involved. In asserting their gendered authority to place White women on a pedestal of feminineity, Black men in interracial relationships with White women are also asserting their right to embody a normative masculinity from which they have been historically excluded. Thus Fanon's prescient explanation of how Black men can grasp White civilization and dignity by grasping the White breasts remains valid in the twentyfirst century. Through partnering with White women, Black men escape the traps of degraded masculinity and offer the possibility of fancying themselves as privileged gentlemen, White knights to their, literally, fair ladies...” (p. 495).

Hughes (2003b) provides more reasons that Black males cited for courting and marrying women outside of their race. Hughes (2003b) cited a writer as saying that some Black men seek physical qualities such as “... long hair, light eyes, pale or caramel skin tone-describe women of Asian, Hispanic or multiracial descent...” (p. 70; Jones \& Shorter-Gooden 2003, pp. 117 and 178). Another writer is cited as saying that other reasons: “... include allegations that the Black woman is attitudenal, selfish, lazy and sexually uptight...” (Hughes, 2003b: p. 74). Hughes (2003b) adds that some Black women also appear to support Black men who date outside of their race, instead of condemning them. Also in other cases, Hughes (2003b) cited a writer as saying that Black women also influence Black men to marry outside of their race “... by unwittingly spreading negative ideas about other Black women in front of their male children” (Hughes, 2003b: p. 74).

On the topic of Black men choosing White women over Black women because they are "nice", Morgan and Bennett (2006) write: "Thus we often hear that Black men are choosing White women because they are 'nice, gentle, know how to treat their men, etc.,' in short, because they conform to standards of femininity from more than a century in the past” (p. 495). According to Rogers (1944):

\footnotetext{
"A black man of social standing rarely, if ever, marries a woman of his own complexion. In the West Indies one who does so would be charged with having done nothing to elevate his race... The black man desires the white woman not for what she is, but rather for what she represents, that is, better social and economic opportunity, while the white man desires the black woman not for what she represents but for what she is. The urge of the former is sociologic; of the latter biologic. The black as a rule, seeks gain or prestige; the white sensual, or sensuous, love...” (pp. 69,93).
} 


\section{Calls for Black American Women to Date or Marry Whites and Other Non-Black Men}

As a result of all of the examples presented above, there are calls from the media, academia and some Black women who are already in interracial marriages for Black women in general in the United States, especially native-born, to start dating and marrying White men and other non-Black men. In a review of the book Is Marriage for White People? (2011) by Ralph Banks, Banard (2011) writes:

"What to do about the black family is a dilemma that has preoccupied sociologists, psychologists, journalists, screenwriters, novelists, and ordinary people for decades. Few have unreservedly advocated the refreshing solution Banks offers: interracial marriage. While black men have long felt free to choose white mates, he notes, black women are 'more segregated in the intimate marketplace than any group in American society”' (p. 90).

It has been noted that interracial marriages including Blacks last longer than Black-Black marriages. According to the study of Jones (2010): "In this sample, there are a lower number of interracial marriages that end in divorce compared to White-only and Black-only marriages. Specifically $25.1 \%$ of interracial marriages ended in divorce, compared to $30.9 \%$ of White-only marriages and $37.2 \%$ of Black-only marriages” (p. 247). According to the study of Wong (2003), Black American men who intermarry, had less difficulty in staying married than their counterparts who intramarried: the mean duration is 8.667 years for intermarried Black men and 8.357 years for their intramarried cohorts. Wong (2003) adds that the percentage of "... the interrupted marriage spell for the intramarried families exceeded that for the intermarried by $16.2 \%$ ” (p. 813).

In addition, due to their increasing gains in higher education and entrance into high-paying professions, Black American women also find it difficult to marry Black men of similar social status (Crowder \& Tolnay, 2000; Fenyo, 2001; Kalmijn, 1993; Lichter et al., 1991: pp. 844-845; McClain, 2004; Mills et al., 1999; Porter \& Bronzaft, 1995; Qian, 1997; Wilson, 1987; Wong, 2003). Also, up to one million Black males are in prison or under the control of the criminal justice system (Lichter et al., 1991: p. 846; Williams, 2003), and in the military overseas, where they tend to meet non-Black women. Williams (2003) points out that in 2000, there were 791,600 Black males (almost half of those incarcerated) incarcerated in American jails and prisons (p. 30). As of 2000, there were 272,818 (20.1\% of total) African Americans in uniform in the US military, with males accounting for over 200,000 (The New York Times Almanac, 2004: p. 153).

Crowder and Tolnay (2000) point out that from 1970 to 1990 , the proportion of African American women age 18 and over, who were married declined from $62 \%$ to $43 \%$. In 1990 , 35\% of African American women under age 35 had never been married. In 1970, that figure was $49 \%$ (p. 792). As of March 2000, there were 562,000 non-Hispanic Black men and 498,000 non-Hispanic Black women who were unmarried partners. There were 4,294,000 Black men and 4,097,000 Black women who were

3“Table 59. Households, Families, Subfamilies, and Married Couples: 1980 to 2010,” 2012. Statistical Abstract of the United States. United States Census Bureau. Retrieved on March 22, 2012 from:

http://www.census.gov/compendia/statab/2012/tables/12s0059.pdf married spouses (Fields \& Casper, 2001: p. 7).

Porter and Bronzaft (1995) assert “... that as Black single women seek good educations and high-paying jobs, they find it more difficult to locate suitable marriage partners of any race" and that many of those educated black women "will accept nothing less than a mate of similar educational level” (p. 163). They claim that the higher the level of education a Black woman has, the higher her chances of divorce. They point to claims that the sometimes aggressive and violent behavior of Black men towards Black women are due to "... their attempts to adopt White men's role...” and that Black men's inability to fully participate as men, like that enjoyed by White men in the society, “... exacerbates Black male/female tension” (p. 163).

In the United States where Blacks, Whites, Asians, Hispanics and other races will live together for the rest of time. Kennedy (2002) provides an account of Harvard University Sociologist, Orlando Patterson's suggestion that Black women should attempt to meet other men of different races and ethnic backgrounds. According to Kennedy, Patterson suggests removing the racial barriers within the marriage market will benefit Black women, "because large numbers of white men are and will increasingly become open to marrying black women, if given a chance.” Patterson also notes that if only one out of every five non-Black men "were to court black women, the pool of potential spouses available to those women would immediately double.” According to Kennedy, Patterson claims that: “... this would be good not only because it would make marriage more accessible to black women but also because larger numbers of white (and other) suitors might well fortify black women in their dealings with black men. As Patterson sees it, by forswearing nonblack suitors, many black women have senselessly put themselves at the mercy of black men, who have declined to be as accommodating as they might be in the face of greater competition" (Kennedy, 2002).

Hughes (2003a) quoted a 24-year-old Black woman who is a native of Memphis, Tennessee, as saying that: "Your soul mate may not be what you expect. He may not be this tall, bald, chocolate-covered Brother; he may be this beautiful, blondhaired, blue-eyed man, or this beautiful yellow man. He can be Asian, Spanish, Arabian, anything, you never know who you're going to fall in love with, or who is going to love you the way you need to be loved. So why wait on a Black man?” (p. 56).

Hughes (2003a) also cited a writer as saying: "If Black women are going to have partners they're going to have to look at Italian men, Latino men, men of other ethnic groups... Black women have to open doors. They have to give themselves more options" (p. 56).

It is useful to point out that with all of the suggestions above for Black American women to date and marry White men in particular, the most recent numbers actually show a very substantial decline in marriages between Black women and White men in the United States from 2009 to 2010. For example, while the number of Black husband and White wife married couples increased from 354,000 to 390,000 (36,000 increase) from 2009 to 2010; from 128,000 to 132,000 (4000 increase) for Blacks married to people of another race that were not White; the figure for White husbands and Black wives declined from 196,000 in 2009 to 168,000 in 2010 (a decline of 28,000) 3.

This brings us to the question: With all of these factors, why then is the vast majority of Black American women not marrying outside of their race as has been suggested above? 


\section{Why Do Black American Women Turn down Courtship Requests from Non-Black Men?}

An interesting observation of the tiny fraction of Black women who marry White men in the United States is that a significant number of those Black women actually marry foreign-born White European men and Jewish men. Also, a significant number of foreign-born Black women tend to marry White men in the United States. Black men, however, tend to marry native-born White American women, when compared with Black women. For example, according to research by Cready and Saenz (1997), 67\% of Black husbands who marry outside their race married "an Anglo", compared with 51\% of Black wives (p. 343). Research findings by Model and Fisher (2001) show that more West Indian Black females who arrived in the United States as children, and native-born (in United States) West Indian females, are more likely than African American females to be in a romantic relationship with White males (p. 182).

Kalmijn (1993) points out that marriages involving Black women and foreign-born White men comprised a significant proportion of interracial marriages involving Blacks. In 1986, such marriages represented 28 percent (p. 140). Within the Black population in the United States, Cready and Saenz (1997) note that "only 1.5 percent and 2.4 percent of native-born African American husbands and wives, respectively, married a foreign-born Black” (p. 343). Also, research by Romano (2006: pp. 123-124), Kaba (2011a: pp. 168-169), and Brettschneider (2010) all provide examples of visible or significant interracial romantic relationships, including marriages between Blacks and Jews in the United States.

Banard (2011) writes of Black women that: "They view interracial relationships as too complicated and see partnering with black men as an expression of a larger commitment to the race itself; often, black women aren't as attracted to men of other races as they are to black men" (p. 90). Kitwana (2002) presents an account of a professional Black woman writing about her difficulty in meeting the right Black man. According to the account, this professional Black woman claims to have achieved a lot in her life, including attaining a very good college education and getting a very good job. One of her difficultties, however, says this woman is of “... the sense that my choices are fewer, chances dimmer, comes mainly because I am a black woman trying to love a black man” (p. 110).

According to the study of Robnett and Feliciano (2011) on the preferences of various racial and cultural groups in the United States on their selection of potential mates on an internet dating website, $76.5 \%$ of Black women (567 sample size) exclude White men, 92.24\% exclude Asian men, 63.14\% exclude Latino men. Also $45 \%$ of Black women said they prefer their own race. For Black men (401 sample size), 11.5\% exclude their own race and $23 \%$ prefer their own race; $71.32 \%$ exclude White women; $71 \%$ exclude Asian women, and 39.15\% exclude Latina women (p. 815). The fact that up to 4 out of every 5 Black women excluded White men as a potential partner is very significant. This is partly due to the fact that while Black Americans are reported to be at least $21.68 \%$ White or European (Jin et al., 2011: p. 2), there are a lot more Black females who look almost White in complexion or have very light skin than Black men. According to Rogers (1952), one important proof of the number of Black males who crossed the line to live as Whites was that “... very fair Negro women are much more in evidence than very fair Negro males” (p. 200). Kaba's (2012b) study of 100 prominent Black Americans from all walks of life aged 25 to 45 shows that $47 \%$ of them are light skinned, but of the 34 women in the study, 53\% are light skinned; and of the 66 men, 44\% are light skinned (p. 14). Interestingly, light skinned Black American women, it is observed, tend to prefer not just Black males, but dark or brown skinned Black males. Or that these dark and brown skinned males tend to prefer them. Rogers (1944) points out that:

“... in the United States where intermarriage is unpopular light girls will marry dark men. As was said, whiteness is a standard of social value, and certain black men, feeling greatly the handicap of color, desire to identify themselves with white, and failing that, as near to white as possible. Besides, to be seen with such a woman makes them the envy of certain Negroes... Black men, in short, win 'light' women for the same reason that plain men are usually more successful suitors than handsome ones. The former, in endeavoring to atone for what they consider a defect, are less proud and more considerate. I have this statement direct from the lips of many of these 'light' women themselves. One of them told me that there is hardly anything black men will not do for her. Another who 'passed for white' told me that she was prompted to accept her husband not because she really loved him but because he was so very attentive." "Kindness," she said, "goes a long way toward winning a woman.” (pp. 71-74).

In this section of this article, I will present the following eight interrelated factors that have contributed to Black American women resisting interracial romantic relationship requests or courtship, including marriage from White men and other non-Black men in the United States: 1) History of Slavery and Rape/Forced Relationships; 2) Concubinage/Politics/Laws Preventing Blacks from Interracial Marriages; 3) Harsh and Cruel Punishment of Black Males and Females; 4) Maintaining Racial Cultural Heritage and Communities; 5) Fear of Perception of Being a Prostitute; 6) Physical Appearance or Attraction/ Body Hair; 7) Education and Financial Success and Concern about Transfer of Wealth; and(8) Religion/Religiosity. These eight factors combined have at least three important characteristics: 1) Importance of history; 2) Economics; and 3) The importance of gender as a variable, meaning that there are many important instances when gender becomes a stronger or more important variable than race or ethnicity.

\section{History of Slavery and Rape/Forced Relationships}

By the second decade of the twenty-first century, the diagnosis of Post-Traumatic Slave Syndrome has been established to explain the painful experience and legacy of slavery going on at this moment. According to Degloma (2009): “Advancing a collective experience framework, proponents of Post-Traumatic Slave Syndrome claim that the psychological impact of American slavery spreads beyond those who directly experienced those events to reach present generations of African Americans” (p. 111; also see Green and Darity Jr., 2010). One of the most disturbing aspects of slavery and Jim Crow is the rape and forced sexual relationships that Black people, especially Black females, experienced in the United States. This tragedy is so hurtful that it is one of the most im- 
portant factors causing the vast majority of Black females not to get involved in interracial romantic relationships with Gentile European American men and other non-Black men. Black women want to show that unlike previous times they now have control over their bodies.

Yarbrough (2005) points out that: "In the eyes of many ex-slaves, relationships between whites and blacks were usually matters of forced sex between the powerful and the powerless: '[I]mmoral white men have, by force, injected their blood into our veins...”' (p. 560). Yarbrough (2005) adds that:

"The dynamics and differentials of power between masters and slaves complicate the notions of consent and choice. The subtext for interaction of this sort is the threat of violence: both slaves and masters recognized that masters could force their will upon slaves by means of physiccal punishment. The prospect of violent reprisal impinged on decisions by slaves to comply with or resist the sexual demands of masters... Ellen Sinclair recounted the incestuous tangle of relationships on the plantation where she grew up: 'Ol' man Anderson he hab a daughter by one of he slaves and he son hab a chile by dat daughter [his half-sister]. Dey mek de wimmen do what dey want and cose, dey slaves and coultn' help deyself”' (p. 565; also see Belknap, 2010: pp. 1089-1090).

According to Millward (2010): "White men could legally marry white women and at the same time force their sexual desires upon enslaved women. While the laws of slaveholding supported violations by slave owners against enslaved women, legislation also erased evidence of bondwomen's intimate relationships with enslaved men. As human property, enslaved women and men were legally 'incapable of civil marriage..."” (p. 22). Millward (2010) adds that:

"Early laws of colonial America reveal planter dependence on the natural reproduction of the enslaved population. In 1662 the Virginia state legislature determined that racial chattel slavery would be a permanent, inheritable condition by asserting that the status of the child follows that of the mother. If the mother was enslaved, so too would be the children, regardless of the status of the children's father... This law ensured that children of free black men and enslaved women also faced a lifetime of enslavement and that children descended from white men could not lay claim to their fathers' free or Christian status. The laws of this era privileged white male authority: whereas the 1662 law upheld the power of a slaveholder to engage in relations with enslaved women, a 1664 law of Maryland criminalized relationships between white women and black men... A white woman who married a black man was declared a 'slave' for the duration of the life of her spouse. Any children born to these women became slaves. As these early laws of slavery reveal, interracial relationships often held legal consequences for those who were not part of the power structure” (p. 24).

Firmin and Firebaugh (2008) also note that: "Caucasian and African American Romantic relationships are not new and evidence suggests their occurrence from before the time of slavery.

\footnotetext{
${ }^{4}$ Peterson, James B. 2012, June 17. “The Original Deadbeat Dads,” Dominion of New of York. Retrieved on June 19, 2012 from: http://www.dominionofnewyork.com/2012/06/17/the-original-deadbeat-dad s/
}

During slave times opposition between these two races was exacerbated by some slave owners raping African American women. Evidence also suggests that some Caucasian women used African American slaves as concubines” (p. 782). Hughes (2003a) cites a scholar by writing that: "There was a time when Black women considered interracial dating, dating White men in particular, as something no respectable woman would do because of the widespread belief that men of other races are only interested in Black women for sexual reasons... And the other [deterring] factor is the legacy of slavery. Black women did not have control of their sexuality during slavery, so during the post-slavery period they took control. And part of what evolved from that [newfound control] was an avoidance of men other than Black men" (p. 56). Cose (2003) writes that: "For years, there has been a general assumption that while black men were comfortable dating white women, black women (for many reasons, some having to do with exploitation dating back to the time of slavery) generally steered clear of white men”(p. 46).

\section{Concubinage/Politics/Laws Preventing Blacks from Interracial Marriages}

A very important factor contributing to Black American women turning down romantic relationship requests from White Americans and other non-Black men is the centuries-long belief by these White men in the country in treating Black women as concubines instead of standing up and taking responsibility and accountability and engage in committed relationships. This behavior, which has been either due to the individual White male himself or it is due to politics and law (Fryer Jr., 2007: p. 74; Strub, 2007)—making it illegal to marry Black women, but will have children with these Black women and abandon their own children and let the Black women and their families raise the children. Scanlon (1998) writes about Black women in the Caribbean and their experience and the issue of illegitimate births: “... the rate of illegitimate births to be 75 percent... the common problems of widespread concubinage and paternal desertion... 'The only fulfilled woman is the one who uses her reproductive organs'... pointing to the problem of single mothers' abandoning children” (p. 63; also see Oakley, 2007: p. 108; Peterson, $2012^{4}$ ).

In other instances, these men enslaved their own children. For example, the late abolitionist, Frederick Douglas, writes that his own White slave master was said to be his father: "If the lineal descendants of Ham are alone to be scriptually enslaved, it is certain that slavery at the south must soon become unscriptural; for thousands are ushered into the world, annually, who, like myself, owe their existence to white fathers, and those fathers most frequently their own masters" (Douglas, 2002: p. 28).

Although Black women and White men have had far more mating than Black men and White women in the history of the United States, most White men involved in such relationships have done so by treating the Black woman as a concubine, while Black men and White women carried their relationships "as equal” partners. Scanlon (1998) cites a line in a poem pertaining to the use of Black women as concubines: "I am not your concubine by night. Transformed by memory by day" (p. 59; also see Drake, 1997: p. 104; O’Brien, 2006; Morgan \& Bennett, 2006: pp. 499-501; Rogers, 1944: pp. 28-29, 156 and 202). Sowell (1978) adds that: "An estimated 1 to 2 percent of the children born to plantation slave women were fathered by 
white men whereas in the Southern cities this proportion approached 50 percent. Since only about 6 percent of all slaves were in the cities, while 60 percent were on cotton plantations alone...” (p. 28).

Jeter (1982) cites: “... accounts about Benjamin Franklin and George Washington engaging in sexual affairs with black women and Alexander Hamilton being mulatto and bearing two black sons. [and]... the notorious story of a Thomas Jefferson/ Sally Hemings relationship" (Quoted in "Marriages between Blacks and Whites" section of article). Camp (2000) writes that: "Jefferson was perhaps the most striking and articulate example of the fusion of American slavery with American freedom. That he had an ongoing sexual relationship with an enslaved woman only deepens Jefferson's embodiment of the contradictions that constitute both this nation and the South.” (p. 275). Camp (2000) continues:

"Sally Hemings bore Thomas Jefferson six children, four of whom lived beyond childhood. Jefferson's appeal for Hemings may have been the relative privileges he could and did offer to her and her children. It may be, too, that Hemings more or less assumed she would have a white paramour: her father was white, as were both her grandfathers; for two generations before her, black women in her family had engaged in sexual relations with powerful white men. Hemings's possible attractions for Jefferson include her renowned beauty, their shared lives in Paris and at Monticello, as well as the fact that he could never marry her, which allowed him to remain true to the pledge he made to his dying wife that he would never marry another”(p. 276; also see Washington-Williams \& Stadiem, 2005).

Writing about Black women in the Caribbean during slavery, Soomer (2000) points to a study by a scholar:

"Bush points to a variety of connections made between the robust nature of African women and animals. These women were perceived to have no problems bearing children and were expected to serve as wet nurses for their more fragile counterparts. She adds that, 'despite the unflattering picture painted by white men, in practice the physical appearance of black women failed to repel them sexually.'... This would account for the increasing number of people of mixed ancestry found in the Caribbean, especially in the French colonies and Jamaica. It would also explain the expected concubinage and prostitution of black and colored women. These facts, according to Bush, point to the hypocrisy of white males during slavery. For example, in San Domingue (Haiti) at the time of the revolution in 1789, there were approximately 400,000 slaves, 30,000 free coloreds and 20,000 whites” (p. 4).

According to Millward (2010): "The placage system and the facility of manumission within Spanish and French colonial laws produced a large free black class prior to and after the Louisiana Purchase of 1803. Some Louisiana planters appear to have delighted in attending social functions with their black mistresses while their white wives pretended to be oblivious. Others participated in buying and selling bondwomen in the "fancy girl" trade, where slaveholders purchased women for their sexual gratification" (p. 22). According to W. E. B. DuBois: “... having finally gotten myself born, with a flood of $\mathrm{Ne}$ gro blood, a strain of French, a bit of Dutch, but thank God!
No 'Anglo-Saxon,' I come to the days of my childhood” (Lewis, 1993: p. 26).

According to Millward (2010): “Given the complexities of sexual relationships in which it was impossible for a woman to withhold consent, and human emotions being as fraught as they are, it is not surprising that dialogues about enslaved women's sexuality and their experiences with white men, in particular, remain contentious. Was an enslaved woman a mistress, a concubine, a forced breeder, or an unwilling victim of the slaveholder?” (p. 23). According to Jacobs (2002):

"In general, interracial relationships between white men of the colonizing, dominant group and nonwhite women of colonized, conquered, and/or enslaved groups have been tolerated. Although laws in many colonies and states forbid interracial marriage between white men and black women, for example, many white slave owners commonly engaged in forced sex, concubinage, and informal relationships with their female slaves without social opprobrium... As we shall see, relationships between white men and Indian women were similarly tolerated within American society. Liaisons between white men and nonwhite women did not violate the hierarchical order that developed between European Americans, African Americans, and American Indians. Rather, they represented extensions and reinforcements of colonialism, conquest, and domination” (p. 31; also see Malherbe, 2006; Mitchell, 2001: pp. 65-66).

In an article about the following Black women: Harriet Jacobs, Billie Holiday and Sister Souljah, Pittman (2007) presents this quote: " $[B]$ lack women writers responded to the myth of the black woman's sexual licentiousness by insisting fiercely on her chastity. Fighting to overcome their heritage of rape and concubinage,... they stripped the characters they created of all sexual desire, imprinting instead the 'purity,' the sexual morality of the Victorian bourgeoisie” (p. 49; also see Fisher \& Wiebe, 2003).

Writing about the plight of Black women in Louisiana from the 1700s Brattain (2005) points out that: "Spanish colonial officials, who took control of the territory in 1769, found it equally difficult to prevent interracial sex, even though prohibitions on marriage and on public sexual affairs outside of marriage-known legally as 'concubinage'-remained in place. Indeed interracial unions occurred often enough that the French and the Spanish legal systems recognized three distinct populations: Europeans, free people of color, and slaves" (pp. 628-629). During the the first few decades of the 1900s, Brattain (2005) points out that: “'Various kinds of disguises have been utilized by parties to conceal the relation of concubinage-housekeeper, storekeeper, cook, maid, nurse, niece, sister-in-law, etc.'... The first five categories were particularly meaningful for black women and white men, as black women more often held such jobs in white households" (pp. 639-641).

Today, most Black American females, including those in college or even high school, would only consider White American males or other non-Black males courting them if they are willing to be in a committed relationship, where they can be seen in public by everyone and would accept no concubinage activities. McClintock's (2010) study of interracial romantic relationships among undergraduate students at Stanford University quoted one of her subjects, a White male as saying: 
"This sense of novelty in having an interracial partner was also expressed by a White male, who commented: “Least I've gotten some different ethnicity. I haven't gone out with a Black girl yet. I feel like that's something I ought to do" (p. 67).

As a result, McClintock's (2010) study finds that Black females were least likely to be involved in "Hookups"-having sex with someone without any commitment or relationship. Of the 1368 students in her study, McClintock (2010) finds that:

"For example, Asian women and Black men are overrepresented in hookups, compared to Asian men and Black women (96 Asian women to 54 Asian men and 61 Black men to 39 Black women)... White and Black men and Asian women participate in significantly more interracial hookups than their same-race other-gender peers, and White men and Asian women also participate in significantly more interracial dates... Although the differences in rates of interracial partnering are not always significant, White women display a higher homophily bias than White men in all relationship forms, and Asian women display a lower homophily bias than Asian men in all relationship forms. The gender difference among Blacks is not consistent: In hookups, the homophily bias is stronger among Black women, in dates there is little gender difference, and in long-term relationships the homophily bias is stronger among Black men. Hispanic students generally have a low homophily bias and display less gender difference in homophily bias compared to the other groups... Black women are somewhat overrepresented in dates, compared to their representation in hookups and relationships...” (pp. 56-66).

\section{Harsh and Cruel Punishment of Black Males and Females}

One must never underestimate the continuous severe punishment of Black people by people of European descent in the United States, the New World and the Old World (Africa, Asia and Europe) in the past five centuries as a contributing factor as to why Black American women refuse to date and marry Whites and other non-Blacks. From severe punishment of Black girls (including handcuffing a six-year old Black girl and taking her to a police station due to a claim that she was disruptive in school in the state of Georgia by government officials) and women (Strauss, 2012 ; Smith, 2012 ${ }^{6}$; Salomon, 2011 ${ }^{7}$ ). According to a March 12, 2012 study released by the United States Department of Education, among boys in school, $20 \%$ of Black males and $7 \%$ of White males were suspended out of school and among girls, $11 \%$ of Black girls and 3\% of White girls were suspended out of school (US Department of Educa-

\footnotetext{
${ }^{5}$ Strauss, Valerie, 2012, May 17. "6-year-old handcuffed for throwing tantrum in school," Washington Post. Retrieved on May 9, 2012 from: http://www.washingtonpost.com/blogs/answer-sheet/post/6-year-old-handcu ffed-for-throwing-tantrum-in-school/2012/04/17/gIQA6KplOT_blog.html ${ }^{6}$ Smith, Mychal Denzel, 2012, April 24. "Too Young: Six-Year-Old Girl Arrested for a Temper Tantrum,” Ebony. Retrieved on May 9, 2012 from: http://www.ebony.com/news-views/six-year-old-girl-arrested

${ }^{7}$ Salomon, Sheryl Huggins, 2011, November 7. "An Outrage: NC Black Women Were Sterilized,” The Root Magazine. Retrieved on May 9, 2012 from:

http://www.theroot.com/buzz/outrage-nc-black-women-were-sterilized

${ }^{8}$ Burton, Nsenga K. 2012, February 1. "White Women and 'Blame a Black Man' Syndrome,” The Root Magazine. Retrieved on May 9, 2012 from: http://www.theroot.com/buzz/lwhite-women-and-blame-black-man-syndro me
}

tion, 2012: p. 3); false charges against Black males and severe beatings and killings of Black boys and men by White Americans and others to this day (Burton, $2012^{8}$ ); the extremely high incarceration rates of Black boys and men in the United States (Alexander, 2010; Bobo, 2009; Bobo \& Thompson, 2006; Kaba, 2010); and the constant public humiliation of Black people in the United States, including the first Black President, Barack Obama, Black legislators and other prominent and not so prominent Blacks, who have suffered all kinds of abuse and humiliation from Whites. But President Barack Obama and other Black leaders always show calm temperament and never attempt to fight back or take revenge for their humiliation, and quick to publically forgive those people. As Kaba (2011c) points out in an article entitled: "Race, Conquest and Revenge: Why Do Black People Resist Racial Revenge?” Black people world-wide are the one group who have refused to take revenge against people of European descent and also against those of other racial groups for all of the humiliation and terrorization they have suffered under them. However, Black women might use these experiences and decide not to get involved with people who treat them and their male children, husbands and relatives in this manner. Might it be that, because of the almost one million Black males in prisons in the United States where they are “... paid 4 cents to 20 cents an hour" to work in White communities (Kaba, 2010: p. 118; also see Blackmon, 2009; Taslitz, 2009: pp. 393-394) a reason why most Black women do not want to get involved in romantic relationships with White men and other non-Black men? In June 2006, of the 2,042,100 males in local jails, State or Federal prisons, non-Hispanic Whites males accounted for 718,100 (35.2\%), Black males accounted for 836,800 (41\%) and Hispanic males accounted for 426,900 (21\%) (Kaba, 2008a: p. 330).

The late Black American abolitionist Frederick Douglass wrote about his disapproval of the way Black women were beaten by White men during his time. For example, Millward (2010) points out that, "Frederick Douglass depicted the violent whipping of his aunt Hester" (p. 23). W. E. B. DuBois notes that: "I shall forgive the white South much in its final judgment day: I shall forgive its slavery, for slavery is a world-old habit; I shall forgive its fighting for a well-lost cause... I shall forgive its so-called 'pride of race,'... but one thing I shall never forgive, neither in this world nor the world to come: its wanton and continued and persistent insulting of black womanhood" (Morgan \& Bennett, 2006: p. 486). Writing about Black women in the Caribbean during slavery, Soomer (2000) points out that: "There was no difference in the punishment of men and women on the plantations. Women were often subjected to whipping by male slave drivers or overseers. The slave owner was usually the one to inflict corporal punishment. In the post 1820 period there were attempts to improve these conditions and in 1823 floggings of women became illegal. Before this period however, all women even if pregnant were stripped and beaten publicly" (p. 7). Perry and Sutton (2008) examine:

“... the broad public prejudices and hostilities against interracial relationships, and more concretely, how these negative reactions to sexed and raced border crossings might condition violence against those in such relationships. They provide the context and pretext in which perpetrators engage in a particular form of hate crime. We argue here that the 'ethnosexual imaginings and ideologies' noted above often manifest themselves in violent 
behaviour intended to police the colour line, by meting out punishment to transgressors. We open with consideration of the legal and cultural discourses that provide such a hostile environment for intimate inter-racial relationships. We then turn to how this context facilitates violence directed at those involved in such relationships” (p. 240).

According to Millward (2010), during slavery: "Enslaved women in the American South lived in constant fear of sexual exploitation by both white and black men. Bondpeople recounted the violence inflicted upon enslaved women in printed biographies and oral interviews” (p. 23). In discussing some Black Americans' reasons for leaving the United States and go into exile, Mitchell (2006) writes: “... whether the future of black Americans lay within or outside the United States. Potential migrants expressed their dissatisfaction in terms of black manhood denied and assaults on black women that threatened the purity of the race. In explaining their desire to leave for Liberia in 1891, for instance, one group from Arkansas cited disfranchisement and the fact that black men were murdered at the hands of mobs, leaving their women vulnerable to rape by white men" (p. 689).

Porter and Bronzaft (1995) point to the claim that the realizetion that educated and professional black women find it disturbing that black men cannot serve as protectors of their female counterparts in the society: "Slavery and racial oppresssion have led to distrust, envy, and disloyalty between Black men and Black women" (p. 163). Wickham (2002) writes of a “... 1951 case in which matt ingram, a black sharecropper, was jailed in North Carolina on a charge of 'rape by leer' for staring at a white woman from a distance of seventy-five feet. Ingram spent two and a half years in jail for this "reckless eyeballing' offense” (Wickham, 2002: p. 7; also see Blackmon, 2009). It is noted that: "In the history of the United States, the fraudulent rape charge stands out as one of the most formidable artifices invented by racism. The myth of the Black rapist has been methodically conjured up whenever recurrent waves of violence and terror against the Black community have required convincing justification” (Morgan \& Bennett, 2006: p. 495).

It is also important to point out that the extremely high incarceration rate of Black males has not only contributed to Black females deciding not to date or marry Whites and other non-Blacks because some might see it as a conspiracy to remove as many Black males as possible out of the general society, which might pressure Black females to accept concubinage relationships from White men, but it has also cause the almost stagnation of the Black population in the United States and causing problems with family formation. This is causing a serious threat to the economic, social and political gains that Blacks have made in the post World War II period. The average Black woman is now going for years at a time not having the required 2.1 children needed to sustain the Black population (On the other hand immigration of Black people into the United States is the most restricted among all racial/cultural groups accepted into the country. According to Kaba (2010), in 2002, 2003 and 2004, the total fertility rate (children born per woman) in the United States was lower for Black females than for White

${ }^{9}$ Maillard, Kevin Noble. 2012, May 1. "Do barriers to Interracial marriage still exist?” The Grio. Retrieved on May 1, 2012 from:

http://www.thegrio.com/news/do-barriers-to-interracial-marriage-still-exist. php females. In 2003, the fertility rate for Black females in the United States was 1.999 children born per women, but the rate for White females was 2.061 children born per woman. From 2000 to 2007, the Black American population increased by only 9.8\%, but it increased by $26.3 \%$ for Asians and $28.9 \%$ for Hispanics (pp. 111-112,115-120). This has implications for Black females because the study of Kaba (2008b) entitled "Sex Ratio at Birth and Racial Differences: Why Do Black Women Give Birth to More Females Than Non-Black Women?” shows that regardless of geographic location, compared with females in other racial groups, females of sub-Saharan Black African descent tend to give birth to more girls (sex ratio at birth) - 1.03 Black baby boys born for every 100 Black baby girls born versus 1.06 baby boys born for every 100 baby girls born in the world (pp. 141-142).

\section{Maintaining Racial/Cultural Heritage and Communities}

One of the most important reasons that not only Blacks and Whites but other racial and cultural groups have presented in opposing interracial marriage or romantic relationships is to maintain their racial or cultural heritage (Kalmijn, 1993; Kennedy, 2003; Leslie, 1996; Storrs, 1997; Yancey \& Yancey, 2002). Storrs (1997) notes that: "Racial communities also disapproved of interracial relationships which provoked challenges to both black and white identity. For African Americans, marrying outside of one's race was often perceived as a sign of disloyalty. Despite this ostracism, African Americans articulated strong black identities” (p. 326). According to Morgan and Bennett (2006):

"In actuality, for African Americans of both genders, interracial relationships are not simply about individuals in a multicolored bubble looking for 'true love' beneath a romantic rainbow. Choosing to intermarry or not to intermarry involves love, commitment, promises, memories, and culture- and community-building that reinforce cultural knowledge... Intermarriage in the United States will not dismantle the nations of China, Japan, Korea, etc. Because African Americans are a minority community without a clear nation of origin, interracial marriage raises practical concerns regarding the endurance, independence, and uniqueness of Black communities and whether their cultural practices are in jeopardy. These are concerns raised when any minority community, in any national context, assesses the impact of romantic, sexual, and marital relationships with members of a majority community. Yet, Black women are dismissed as angry when they express these concerns" (pp. 487-488).

Maillard (2012) points out that: "People date and marry with friends and family in mind. Community reprisal could be a big factor, as blacks and whites may fear reactions from their home communities about their choice of partner. Their personal decision is not so individual-it becomes something larger." 9 Mitchell (2006) writes: "Such concerns would persist, with Marcus Garvey arguing in 1922 that black men needed to strike back on white men trying to get too close to black women." It was important, in his view, to protect "the purity of the black race not only down South, but all through the world... Writers and activists exhorted black women to shun the attentions of white men, believing that 'rape, concubinage, and miscegenation compromised racial reproduction'... This thinking was seconded by Marcus Garvey's Universal Negro 
Improvement Association, which actively promoted 'racial purity'...” (p. 689).

According to Williams (2009), when the late Black American movie and entertainment star Lena Horne married a White man in the late 1940s, she was so worried about the reactions of both the Black and White populations that they kept it secret for years: "In 1947 Horne secretly married MGM musical director Lennie Hayton, a white conductor, arranger, and pianist, in Paris. Fearing negative reactions from both white and African American fans, the couple dated secretly for three years prior to their marriage and decided to continue their clandestine relationship until publicly announcing their union in $1950 .$. Overall, the reasons for Horne's secrecy concerning her relationship with Hayton and the responses it garnered once publicized reflect African Americans' contempt of, ambivalence about, and support for interracial marriage during the 1940s and 1950s" (p. 130).

In May 2003, the CBS television program "60 Minutes” replayed some of its old programs to celebrate its 35th year on the air. Among some of the stories was that of Lena Horne's marriage to a White/Jewish man. Here is a short transcript of the interview:

"Ed Bradley also talked to Lena Horne about her second husband, Lennie Hayton, a musical arranger who was also white and Jewish. For three years, Horne kept her marriage a secret.

'He had more entree than the black men,' says Horne. But did she love him?

'Not at first. I learned to. He loved me very much, and I learned to love him because of how good he was to me, and patient and the things he taught me,' says Horne.

'And he could come in the club with me and ask for this and that and the other and that would happen, where a colored man-I revert to that word, because in those days that's what we said—couldn't get me a job. And I had to love him for that, because you see, then I began to be very hungry for him to see me as black."” (CBS Television "60 Minutes” 2003, May 18). ${ }^{10}$

Walsh (2012) presents this account of a Black man who is married to a White woman, but in opposition to his daughter marrying a White man:

"Notice how Maurice Holland's beliefs about gender cannot be disentangled from his racial notions:

Umm I don't know about my baby, but my older two picked black people to marry. Whether she will or not I don't know. I don't know. (ETW: Will it matter to you?) Oh yeah (Talk about that to me).

Kris. Umm I hope she doesn't. I mean, I don't like white men. In general I don't. It would be hard. Yeah I would not be in favor of that. I couldn't know his white family's outlook, see, about racial things. And it could impact her. How would he raise kids? Ya know? I would be very, very upset if that were the case, a white man. I would actively discourage it. (ETW: What if your son married a white girl. Would you feel the same way?) No.

(ETW: Tell me about that) Because generally the wife

\footnotetext{
$\overline{{ }^{10} \text { CBS Television "60 Minutes," 2003, May 18. "Special: Asking Tough }}$
} Questions,” http://www.cbsnews.com/sections/60minutes/main3415.shtml adapts to and enters into the husband's world. I'd say that essentially is what it is. Ya know? And um, if my son married white, she'd come into his world. And I would imagine if my daughter married white, her life would be in his world. Just the way it is. Maurice married his white wife in 1967” (p. 78).

McClintock (2010) presents this account of a Black female student in her Stanford University study:

"In contrast, Black students, particularly Black women, expressed hesitation to engage in any interracial sexual or romantic partnership (including hookups). When asked whether it was important that potential hookup partners be of her own race, a Black woman seemed uncomfortable, but acknowledged 'Ummm... yeah... it's kind of... it's... it's... yeah... I am a product of my environment. Like, growing up in [city omitted], like, the Black people are pretty much with Black people, like White people are with White people'”' (pp. 66-67).

Henry (2008) writes of a young Black American woman and her apprehension about getting involved in interracial romantic relationships: "However, their interracial relationship is threatened not only by Kenya's own dissonance about dating outside of her race, but also regarding how the relationship will be perceived by her family and friends... In an interview with the Philadelphia Daily News... "[Black female movie star] Sanaa Lathan expressed strong identification with the Something New storyline because, like her character, she has dated outside her race and struggled with feelings of guilt'” (p. 19).

In a study of 100 African American female college students, to determine their rates of interracial romantic relationships, Porter and Bronzaft's (1995) found that $87 \%$ of them prefer Black males, $1 \%$ prefer Whites males, $4 \%$ prefer Hispanic males, $1 \%$ prefer Asian males and $2 \%$ prefer the group of males called "Other" (pp. 167-168). However, 19\% of the students in the study said that they would marry White men if there were a lack of eligible Black men to marry (p. 169). McClain (2004) studied 22 young adults of mixed Black/White parentage over a few years and points out that one of them deliberately sought a dark-skinned Black man to be her romantic partner because she wanted to make sure that her future children were seen and to see themselves as Black (p. 47).

\section{Fear of Perception of Being a Prostitute}

The topic of prostitution is considered very sensitive to Black American women (Crenshaw, 1997: pp. 267-268). This is due to the fact that government laws, in addition to raw human hatred of Black people resulted in very few to no opportunities for any real gainful employment for Black women after slavery, thereby putting them in a position not much better off than slavery. In addition, Black women took the responsibilities of the children that they have with both Black men and White men, since up to this day most White families refuse to acknowledge their family members with Black blood or ancestry. Also, many White men who refuse responsibilities of a committed romantic relationship, can get involved with Black women for paid sexual service (Coleman, 1998: p. 83; Collins, 2003: p. 54). As a result, many Black women find themselves having sex for money with White men, which results in a perception in society that if a Black woman is out with a White man, people in general might think that she is a prostitute, since White men do not 
marry or want to be seen in public with Black women. As Maillard (2012) notes of "Dirty looks on the subway or at the mall. Bringing separate checks to dining couples. Catcalls in the park. Assuming the black partner is a servant or employee." "Walsh (2012) presents this interesting account of one of the subjects (a Black woman) in her study who is married to a White man:

"Dianne Kennedy, a walnut-color with freckles across her nose, has her hair pulled lightly to a bun at her neck. Wearing a white sweater draped over her shoulders, she looked right through me with coffee color eyes as she discussed her strategy for countering the stereotypes of black women, married across the color line, by describing her considerations when out in public with her white husband of twenty years:

One, you got to be more on your P's and Q's. You got to be careful how you act. I would never go out with Michael looking like a tramp. I would not. And I think that's from childhood growing up in the South. You think of a black man with a white woman she'd be all fat and nasty. A black woman with a white guy-that wouldn't look good. Where I come from, she's probably a working girl, if you know what I mean.

The awareness of stories that circulate and impressions others might have of an interracial couple works as a social control mechanism for Dianne who continues after twenty years to consider how strangers might misinterpret her for a prostitute. Dianne was not alone with this concern; two other black women interviewed also made pointed comments about being concerned about their appearance in public with their white husbands and their assumption that black women in the company of white men might be mistaken for prostitution” (p. 78).

\section{According to Sivanarayanan (2005):}

"The sexualization of the image of the black woman becomes almost a constant refrain in succeeding years. At a 1937 New Orleans street revel, the photographer John Gutman took a close-up photo of a nameless black woman who was wearing a white mask. There is a well-dressed young black man standing with her. Interestingly, the photograph is titled: 'In the Background: The Pimp'... As the authors note, there is nothing to indicate that the man standing in the back is a pimp. The photographer presents the viewer with a singular mode of reading the photograph that is transparent and uncomplicated, and Willis and Williams note, 'the couple's color dissuades most viewers from questioning the title'... The association of the black female with sexual labor is extended in other ways too. The New Orleans police department, in the years 1912-1918, passed around "mug shots"-the standard, front-facing police photographs-of dull-eyed black women who were labeled prostitutes, even though the crime they were accused of committing was not prostitution but robbery" (p. 1111).

Foster (2005) points out that: “In 1897 New Orleans mayor

\footnotetext{
${ }^{11}$ Maillard, Kevin Noble. 2012, May 1. "Do barriers to Interracial marriage still exist?” The Grio. Retrieved on May 1, 2012 from:

http://www.thegrio.com/news/do-barriers-to-interracial-marriage-still-exist. php
}

Sidney Story issued an order creating a vice district, which came to bear his name. Established in an area of the city that had long been a location for what at the time were termed 'Negro dives,' Storyville became home to concert saloons, other forms of entertainment, and, most famously, houses of prostitution” (p. 220). Writing about Black women in the Caribbean during slavery, Soomer (2000) points out that:

"In the urban setting, women usually were employed as domestics and often were paid wages. Many slave owners in the towns hired their slaves out as day workers and kept some of the wages while giving the slave the remainder. It was also in this setting that prostitution was rife. Many taverns, usually owned by white women or the colored mistresses of white men, served as brothels. Here, African women were bought and sold for the sexual pleasure of planters or visitors to the islands. Barbados is especially known for 'whore' houses because it was the headquarters for the British garrison and a primary shipping port. Planters in the rural setting also exploited African women in this manner. Female slaves were expected to provide sexual comfort for male visitors to the plantations” (p. 7).

According to Goss (1997):

“In Ar'n’t I a Woman? Deborah Gray white describes the 'Fancy Trade,' the sale of light-skinned black women for the exclusive purpose of prostitution and concubinage as a fairly common occurrence in New Orleans. Charleston, St. Louis, Lexington and even Virginia. The belief that African women were promiscuous (no doubt founded as a result of seeing semi-clad black women on the auction block) generated a widely held belief that black women were immoral and naturally promiscuous. These lighterskinned sisters, thus, were the perfect outlet for the sexual fantasies of owners whose wives often kept their chastity under lock and key" (Quoted from the "third page of a non-pdf" article).

\section{Physical Appearance or Attraction/Body Hair}

In earlier sections above of this article, there was the debate as to which racial groups among women are beautiful and the types of physical characteristics among women that men might consider attractive or beautiful. The truth, however, is that all women from the racial/geographic groups in the Old World (Africa, Asia and Europe) are beautiful! The reason why many prominent magazines have used White women on their cover in recent decades is primarily money-people of European descent have accumulated more wealth (and many might claim at the expense of people of Asian and African descent, see Kaba, 2011c, 2011d) and may demand to see people who look like them on the covers of magazines or else they would not purchase those magazines and the items advertised in them. And like Blacks, Chinese and South Asians, Europeans have over a billion members. For example, there is an estimated 1.2 billion people of Black African descent on the planet, third only to people of South Asian descent (Colonial India today over 1.535 billion as of July 2011: India, 1,189,172,906; Pakistan, 187,342,721; and Bangladesh, 158,570,535), and people of Chinese descent (over 1.337 billion), and ahead of people of European descent (1.1 billion as of 2003) (Kaba, 2011c: p. 97). As a result, magazine editors tend to seek their business. 
Yet, it has been very common in recent decades to see beautiful Black women or non-European women on the cover of those same magazines. Humans' urge for competition, which can occur within families, between neighborhoods, and between ethnic, cultural and racial groups is part of the reason for many individuals' claims of which racial or ethnic group is beautiful. Jones and Shorter-Gooden (2003) note this point: "In a society where the standard of beauty remains European, where beauty still too often defines woman's worth, many black women struggle to feel attractive and thus secure and valued. The pressure to look like someone other than themselves, to look more European and less African, is enormous" (p. 117).

Also, both scholarly literature and popular media across the world claim or portray Blacks and Whites to be among the most beautiful or attractive people in the world (Groves, 1989; Zernike, 2004). This is largely due to the fact that a large proportion of Blacks and Europeans tend to possess the physical characteristics, shapes or features (tall, naturally muscular or toned body, etc.) that most societies associate with beauty or attractiveness. For example, in the United States, the mean or average height of females 20 years and over from 1999 to 2002 was 63.8 inches or almost 5'4" tall. When broken down according to race/cultural background both non-Hispanic Whites and non-Hispanic Blacks are taller than the national average (64.2 inches each for those 20 years and over) and they are also both at 64.6 inches tall for those 20 - 39 years old. For males 20 years and over in the United States during that same period, their average height was 69.2 inches, but 69.7 inches for non-Hispanic White males and 69.5 inches for non-Hispanic Black males. As for their average weight, in the general US population, from 1999 to 2002 the mean or average weight of females 20 years and over was 162.9 pounds. For non-Hispanic White females, it was 161.7 pounds, and 182.4 pounds for non-Hispanic Black females during that same period. For those aged 20 - 39 years, it was 158.4 pounds for non-Hispanic White females, and 179.2 pounds for non-His panic Black females. For males 20 years and over in the US during that same period, their average weight was 189.8 pounds; 193.1 pounds for non-Hispanic White males; and 189.2 pounds for non-Hispanic Black males (Kaba, 2012c: pp. 97-98). Zernike (2004) reported on a large survey called SizeUSA, conducted “... by clothing and textile companies, the Army, Navy and several universities", in which the physical shape of 10,000 Americans in 13 cities nationwide were measured. According to Zernike: “... Black women are larger than other women, but they are also most likely to have the classic hourglass figure. Sixty-four percent of women are pear-shaped, and 30 percent are 'straight,' meaning they had little perceptible waist... median height remained the same (5 feet 4 inches for women, 5 feet 9 inches for men)... Twenty percent of Hispanic women had 'full waists' compared with 10 percent of white women, and 15 percent of black" (p. A1).

Yancey and Yancey (1997) claim in their study of Blacks and Whites who romantically court one another through advertisements, that White individuals tend to be significantly more likely to seek or offer physical attraction, and that they are also less likely to offer financial security, than Whites who court intraracially. They also note that Blacks who seek Whites through advertisements also desire physical attraction. Yancey and Yancey (1997) also note that love and physical attraction have been cited as reasons for interracial romantic unions. Vic- tor Hugo (1802-1885), "Novelist, poet, and dramatist, the most important of French Romantic writers" was quoted as saying of the "mulatto" in his novel Bug-Jargal in which he was said to have made the Black hero say to the White heroine: "Thou art white and I am black but day must join with night in order to bring forth the dawn and the twilight which are more beautiful than they" (Rogers, 1944: p. 123).

Rogers (1944) writes that: "David Livingtone, great missionary, when he saw in Africa black men all about him and he, the lone white: 'One feels ashamed of the white skin; it seems unnatural like blanched celery or white mice'” (pp. 122-123). It has also been written that throughout history, there have been White males and White females who prefer to date or marry Blacks. According to Rogers (1944): "Peter Nielsen, a white ethnologist, who lived many years among the blacks of South Africa, says similarly: 'I have often heard white men who have kept native women say that they found the black or deep brown colour of the native woman far more beautiful... and I have also heard white women of culture and refinement admit that the black or dark-brown torso and tints of the African man have seem to them a more pleasing sight..."” Rogers adds, "I have met Frenchmen, and Belgians, and even Englishmen, who prefer the blackest Congolese to the whitest German” (pp. 115116). Another famous White explorer in Africa, Richard F. Burton adds in describing the beauty of the Blacks he encountered on the continent: "Their well-made limbs and athletic frames... were displayed to advantage... and were set off by opal-coloured eyeballs, teeth like pearls, and a profusion of broad massive rings of snowy ivory round their arms, and conical ornaments like dwarf marling-spikes of hippopotamus tooth suspended from their necks" (Ondaatje, 1998: p. 354). Even during the most racist period in South Africa's history, Maurice Evans (1901-1989), "A grand, robust, highly theatrical British classical actor," was reported to have said of the Black South African male: "When thoroughly washed and duly anointed there is a peculiar richness about his color...” (Rogers, 1944: p. 117).

This now brings us to an important factor that might be contributing to Black women turning down courtship requests from White men in particular in the United States-Body Hair. While White men may have an advantage because they are relatively taller and women or females in general like or prefer tall men, by the beginning of the twenty-first century, a high number of females or women from all racial groups in the United States tend to make it known that they do not seek to be in a romantic relationship with men who have a lot of hair on their body or men who are very hairy. Moreover, research has shown that men of European descent tend to be more hairy than Black men or men from other racial groups. Or that Black men are less hairy than men of European descent. According to Thomas Jefferson (published 1781-1782), the third president of the United States: "Negroes have notoriously less hair than the whites... Besides those of colour, figure, and hair, there are other physical distinctions proving a difference of race. They have less hair on the face and body." 12 Hama (2010) writes of the Africans of Ethiopia and Somalia having "Scantiness of body hair, save for on the scalp" (p. 176). According to Tobin (2006): "There also appears to be some variations in HF [Hair Follicle] density between humans of different ethnicities; Africans and Asians have less densely haired skin than Caucasians” (p. 418). 
This issue is so important for men in the United States that increasing numbers of men in general and White men in particular are finding ways to remove their body hair so that they can stand a chance to win the heart of a woman they are romantically courting. For example, Boroughs and Thompson (2002) write that: "Removing body hair is not new in western cultures. However, historically this behavior has been culturally sanctioned primarily for females” (p. 247). Saint Louis (2001, July 9) points out that:

\begin{abstract}
“AMERICAN women didn't shave their armpits en masse until the 1920s, after a perfect storm of sleeveless dresses and a barrage of advertisements by depilatory makers characterized underarm hair as ugly. Next came the tarnishing of women's leg hair. By the 1930s, beauty writers scolded women with forests under their silk stockings. Decades later, what began as a fad had solidified into custom. Girls coming of age no longer needed to be told their leg hair was unsightly. They got rid of it. Can the same thing happen with men? These days, the hair on men's chests, backs, armpits and even 'down there' has become suspect” (p. E3).
\end{abstract}

According to Heep (1995): “In the United States, women are required to shave their armpits and their legs-many also shave above the knee. Men, in denial of their masculinity, have to have short hair. Facial hair in high ranking, conservative positions is a taboo. Consequently, many men shave their carefully constructed bodies as well. Should hairy men opt not to wax, electrolyte or shave, they are advised to wear an undershirt in order to hide their excessive body hair" (p. 261). Newman (2010, June 15) writes:

\begin{abstract}
"MARK BRYCE, the operations manager at a semi-trailer dealership in Grand Rapids, Mich., has lost most of the hair on his head, but he is 'really good at growing it everywhere else,' particularly on his back, said his wife, Anna, a publicist for Amway. 'My husband is blond, so he doesn't look like a big hairy ape, but he does look like a golden retriever,' she said. For years, before the couple packed for the beach or a cruise, Ms. Bryce shaved her husband's back with a razor in the shower. Then one of her colleagues took a job with Remington, the shaver maker, and Ms. Bryce noticed on the company's Web site a new shaver with a telescoping handle for unaided trimming of back hair. She joked with her former colleague that her husband could use one. Two months ago, it arrived in the mail. 'It works really well,' Ms. Bryce said. 'He doesn't need my help with that anymore, which is nice because I have a lot of other stuff to do besides shave my husband's back.' As hairless torsos have become the norm for male models and actors, below-the-neck hair removal has gone mainstream” (p. E6).
\end{abstract}

According to James (2009, December 10):

\footnotetext{
${ }^{12}$ Jefferson, Thomas. 1781-1782. Notes on the State of Virginia. Electronic Text Center, University of Virginia Library. Retrieved on April 28, 2012 from:

http://etext.virginia.edu/etcbin/toccer-new2?id=JefVirg.sgm\&images=imag es/modeng\&data=/texts/english/modeng/parsed\&tag=public\&part=all

${ }^{13}$ James, Susan Donaldson. 2009, December 10. "Manscapers Mow More Hair, Even Down There,” abcnews.com. Retrieved on March 16, 2012 from: http://abcnews.go.com/Health/GadgetGuide/manscaping-men-shave-wax-b odies/story?id=9293977
}

"Ben, a 6-foot 4-inch, dark-haired, blue-eyed New Yorker, is not a bodybuilder, model or porn star. But the 33year-old never misses his monthly appointment at Manhattan's Townhouse Spa for grooming - not just a manicure and a shave, but a $\$ 150$ back waxing. 'It doesn't hurt that much and the girls appreciate it,' said Ben, who makes infomericals for a living and was shy about going public with his last name. Nowadays, trimming or eliminating unsightly body hair is as 'important to guys' as women, he told ABCNews.com. 'It's like when you're in a bar and you see a girl with terrible nails and cuticles,' said Ben. 'It's a turn off. And, I'm sure the girls feel the same way, especially in the summer at the Hamptons when I walk around with my shirt off. I don't need to have that back hair on display.' Ben is one of many American men who have embraced manscapin-shaving or waxing the heavily forested parts of their bodies. He won't go near the 'nether regions,' but many men do. Hair anywhere except on the head seems to be verboten these days, and the modern male will take the razor where few man have ever gone before."13

According to McCreary et al. (2007): “Men's fitness goals are influenced by the lens through which they view their bodies, which is different from the way women view their bodies. Their increased focus on a muscular, hairless body means that they exercise to enhance their physical bulk and are more likely to engage in depilatory behaviors" (p. 307). Boroughs and Thompson (2002): “... conducted 20 structured interviews with males to investigate several facets of a relatively new phenomenon: the removal and reduction of body hair by men. Seventeen of the 20 participants were Caucasian, two were Hispanic, and one was African American. All participants reported using both cardiovascular and resistance training strategies, and all that were asked to participate in this pilot study did affirm they engaged in the hair removal behaviors and agreed to participate" (quoted in Methods section of article). According to Boroughs et al. (2005): "Of the 118 participants in the study, 75 (63.6\%) answered affirmatively to the question 'Do you or have you recently shaved or trimmed any body hair below the neck?'” (p. 639; also see Boroughs et al., 2010: pp. 726-727).

\section{Education, Financial Success and Concern about Transfer of Wealth}

Although there is the perception that interracial marriages, especially involving Blacks occur among working class or the poor with low levels of education, research actually shows the opposite. According to Walsh (2012): "Drawing on the conventional wisdom circulating as commonsense in 1930, W. E. B. DuBois refutes the assertion that intermarriage is highest among the class with least prestige and property using empirical data on a sample of 9000 to show interracial marriage at that time was most likely among those who had the most contact. Nonetheless, his frame of the issue reflects long held and enduring notions about the types of individuals who intermarry” (p. 76).

Research has shown that people who interracially marry are usually highly educated (Fenyo, 2001: p. 334), and in the case of Black-White marriages or couples, the Black husband is usually more educated than the White wife (hypergamy) and the Black wife is also said to be more educated than the White 
husband (Tucker \& Mitchell-Kernan, 1990: p. 213; Qian, 1997). An article by the Statistical Assessment Service entitled, "Can Intermarriage Make You Smarter and Richer?” reports of a study that supports this claim. According to the article, "In 1990, there were over twice as many married couples in which both of the partners were black than there were couples where only one partner was black. This ratio held constant when a number of factors (employment status, number of children in the household, etc.) were introduced." However, according to the article, when education and income were factored in, it did not remain constant. The article points out that, at lower economic levels, the ratio of both-Black marriages to mixed race marriages leans disproportionately to both-Black couples. The article also points out, however, that, as the income of a Black person increases, the chances of being in a mixed marriage increases “... until at the highest income level $(\$ 100,000$ and above) they are nearly even, with 86,443 both-black couples and 75,410 mixed race couples." A similar scenario also occurs when educational attainment is factored in. Blacks without a high school diploma are more likely to be in both-Black marriages. According to the article: "At the 'non high school graduate' level, there are more than four times as many both-Black couples as mixed race couples, but with each step of educational attainment, the figures get closer. At the 'graduate or professional degree' level they were again almost even, with 160,367 both-black couples and 146,763 mixed race couples" The study then suggests that: “... the data appear to indicate that the more educated you are (or the more economically successful you are), the more likely you are to be in an interracial marriage" (The Statistical Assessment Service, 1997).

According to Qian (1997), in 1980, White wives were 109\% more likely to marry Black men. For African American women: In 1980 , and 1990 , respectively, they were $19 \%$ and $2 \%$ less likely to marry White men who were higher in education, and also they were $10 \%$ and $17 \%$ less likely to marry Hispanic men who had higher levels of education. In 1980, and 1990, according to Qian (1997), Black women were 1\% and 5\% less likely to marry Black men higher in education (p. 271). Model and Fisher (2001) note that African American-White unions tend to be slightly more hypergamous than African American-African American unions, $33.8 \%$ vs $26.2 \%$ (p. 183). According to Wong (2003), from 1968-1997, the mean family incomes (\$35828.44) for intermarried Black men in the United States were 6.3\% higher than their intramarried cohorts (\$33693.25). African American men who out married had 0.4 years more (or $3 \%$ higher) education than intramarried cohorts (12.81 years to 12.41 years) (p. 812). In the study of 40 Black-White couples in four states during the period from 1970 to 1974, in which the couples had dated for an average of 16 months before they got married that Jeter (1982) points to, for four White male-Black female couples “... the black women involved were admired for their independence and self-sufficiency, were pregnant, or desired to marry a man of comparable education and occupational status” (p. 105).

Walsh (2012) tells the story of a Black Husband-White wife with a focus on the high society status of the Black husband:

"But it wasn't about the color line. It was that we were getting too (long pause) too middle-class. That was the worst insult my parents could ever say, 'middle-class'. Jeanne Jamison, age 72 at interview, married a black attorney in 1954. Jeanne Jamison gave many examples of using her husband's prominence and their social class status to 'rise above' criticism. Over the years she used a defiance of convention along with the safe security of social class position as shields strategically employed to deflect criticism, social ostracism and negative comments from others. She gave examples from 'uppity' neighbors in her North east urban neighborhood to school officials who were chagrined to discover 'who we were'” (p. 77).

This brings us to the very important issue of the potential transfer of wealth in interracial marriages, especially those between Blacks and Whites in the United States. Kaba (2011a) points out that the concern about the transfer of wealth through inheritance as a result of death (pp. 124-127) and also through divorce is one of the primary reasons why European American leaders have opposed interracial marriages, because they fear that the White husband might transfer his wealth to his Black wife, because United States law allows the surviving spouse to inherit their estate.

According to Rogers (1944) White Americans “... generally insist on concubinage as the refusal to marry has as its motive the maintaining of social prestige, which is largely economic (Rogers, 1944: pp. 69,93). According to O’Brien (2003): “St. Clair believes that Hagar's black blood precludes her status as legitimate wife and instead suits her to become an enslaved prostitute" ("Sexual Slavery and Social Purity in an Antebellum Context," Section of article). Brattain (2005) presents this important account on this issue of the transfer of wealth in interracial marriages:

"The relationship between J. W. Jones, white, and his 'cook' Amanda Kyle, Negro, seems to have been such a case. Kyle lived in Jones's house from 1904 until 1907 or 1908 and, after that, in a house he built for her on his property. Kyle cooked and kept house for Jones and waited on customers at his store. They did not have children, but, according to the neighbors, 'general talk' was that Jones was 'keeping' Kyle. One acquaintance even claimed to have found them in bed together. Apparently no one ever reported their activity as criminal. The relationship might have never appeared in the record had Jones not left all of his considerable estate, worth approximately $\$ 40,000$ in 1926 , to Kyle, provoking a challenge from Jones's nieces and nephews. In court, the nieces and nephews attacked the relationship and charged that Kyle and Jones had lived together in a state of illegal 'open concubinage.' As defined by Louisiana law, 'open concubinage' was more morally repugnant and damaging to community morals than secret concubinage and was therefore punished by limiting the surviving partner's right to inherit from the other's estate... Kyle denied that she was any more to Jones than his cook, and at least a dozen witnesses so testified on her behalf. Interestingly the legal issue was not the relationship per se, but whether it was open or secret, which had a direct bearing on her right to inherit. The court concluded that KyIe and Jones had been a couple, citing among other evidence her access to Jones's cash drawer and their living together, but the court disagreed with Jones's nieces and nephews, concluding that the relationship was secret. Jones hid his relationship while keeping 'her in his employ ostensibly as cook and housekeeper and assistant in his store ...' In fact, by folding the document so that only the signature lines were exposed, he had even kept the contents of his 
will a secret from the witnesses who signed it. Therefore Kyle was allowed to inherit Jones's estate” (pp. 639-641; also see Foster, 2005: p. 220).

As a result, it is unlikely that there has been a case in United States history where a Black wife inherits $\$ 50$ million or more of her White husband's wealth or inherits that same amount of money from divorce.

The study of Edlund and Kopczuk (2009) on wealth inheritance by women in the United States using estate tax returns from 1925 to 2000 showed that a significant number of women inherited their wealth from their husbands or family members. Edlund and Kopczuk (2009) identified 422 female millionaires in the United States in 1892 and 348 (83.4\%) inherited their wealth. Of 2783 male millionaires, 417 (15\%) inherited their wealth (p. 164). Carlyle (2012) reports for Forbes magazine that in 2012, "The 21 richest women in the world (two women tied at 20th place) have a combined total net worth of \$248.6 billion, or an average of $\$ 11.84$ billion each... The richest, for the seventh year in a row, is Christy Walton, who inherited her fortune-now worth $\$ 25.3$ billion-from husband John Walton after he died in a plane crash."14 Evans (2010) also reported for Forbes magazine that in 2010: “... only four of the 42 women, or $1 \%$ of all Forbes 400 members, are self-made including Gap's Doris Fisher and ABC Supply's Diane Hendricks, who each cofounded a company with her late husband... The other 38 women inherited all or part of their fortunes from their husbands or fathers including three who ranked among America's top 20." ${ }^{15}$ It is widely reported in 2011 and 2012 that the wife (a White American woman) of the late Apple Corporation CEO, Steve Jobs inherited at least part of their $\$ 8$ billion estate.

Kaba (2011a) points out that: "This transfer of wealth actually impacts the Black community more severely, because proportionally, there are fewer wealthy Blacks than Whites and the life expectancy of Blacks is lower than that for Whites. For example, in 2006, out of 94,029,000 White alone males, $6,018,000$ (6.4\%) earned $\$ 100,000$ or more; 299,000 (2.35\%) out of 12,716,000 Black alone males; 2,606,000 (2.7\%) out of 97,550,000 White alone females; and 213,000 (1.4\%) out of $15,413,000$ Black alone females" (p. 127). As for the gender and racial differences in life expectancy, in 2010, the life expectancy of White females was projected at 81.3 years; 77.2 years for Black females; 76.5 years for White males; and 70.2 years for Black males ${ }^{16}$.

There are examples of wealthy Blacks in the United States whose White wives have inherited or received tens of millions of dollars or more in divorce settlement. For example, Sie-

\footnotetext{
${ }^{14}$ Carlyle, Erin. 2012, March 7. “The World's Richest Women,” Forbes. Retrieved on May 9, 2012 from: Retrieved on May 1, 2012 from: http://www.forbes.com/sites/erincarlyle/2012/03/07/the-worlds-richest-wom en/print/

${ }^{15}$ Evans, Katie. 2010, October 25. “America’s Richest Women,” Forbes. Retrieved on May 9, 2012 from:

http://www.forbes.com/2010/10/25/america-richest-women-oprah-walton-w almart-whitman-wealth_print.html

16“'Table 104. Expectation of Life at Birth, 1970 to 2008, and Projections, 2010 to 2020,” 2012. Statistical Abstract of the United States. United States Census Bureau. Retrieved on February 23, 2012 from:

http://www.census.gov/ compendia/ statab/2012/tables/12s0105.pdf

${ }^{17}$ Siemaszko, Corky. 2010, October 18. “Tiger Woods divorce settlement: Elin Nordegren received \$110M payout-report,” New York Daily News. Retrieved on May 9, 2012 from:

http://articles.nydailynews.com/2010-10-18/gossip/27078581_1_elin-nordeg ren-tiger-woods-million-settlement
}

maszko (2010, October 18) reported in the NewYork Daily News that the White wife of Black Golfer Tiger Woods: "Newly divorced from Tiger Woods, Elin Nordegren is cutting back on the help-even though she got a reported \$110 million [divorce] settlement from"17 her husband. Also, Dwyer (2012, January 20) reports for Yahoo News of the divorce of Black professional basketball player Kobe Bryant from his White wife: "Did you know that Kobe Bryant owns three mansions in Newport Beach, alone? No? Let that swirl around for a second, and now learn that Kobe Bryant does not own three mansions in Newport Beach anymore. Those houses, and a princely \$75 million sum, have been sent to Kobe's ex-wife Vanessa in the couple's divorce settlement."18 (also see "Kobe Bryant Divorce,” 2012). ${ }^{19}$ It has also been widely reported that the legal White wives or Common Law wives of the following late prominent Black entertainers benefited or will potentially benefit from their estates: James Brown, Gary Coleman, and Donald Cortez "Don” Cornelius.

By the beginning of the second decade of the twenty first century, a substantial number of Black American females have accumulated substantial wealth through gains in colleges degrees, entertainment and athletics, business, etc. As already noted above there were 213,000 Black women in the United States in 2006 with incomes of $\$ 100,000$ or more. In 2009, there were 566,000 households with Black females with incomes of $\$ 75,000$ or more in the United States. In that same year, there were 12.913 million households with White alone males, 557,000 households with Asian males, and 2.887 million households with Hispanic males with incomes of $\$ 29,999$ or less. ${ }^{20}$ According to Kaba (2012a), there were 3.437 million Blacks aged 18 and over with at least a bachelor's degree, with 2.028 million (59\%) comprising Black women and 1.409 million (41\%) Black men. Of the 1.275 million with master's degrees, 808,000 (63.4\%) were women and 467,000 (36.6\%) were men. Of the 189,000 with professional degrees (such as Juris Doctorates and Medical Doctorates), 119,000 (63\%) were women and 70,000 (37\%) were men. And of the 181,000 with doctorate degrees, 79,000 (43.6\%) were women and 102,000 (56.4\%) were men (p. 138).

Cocchiara and Bell (2006) point out that at least 30\% of Black women and $21 \%$ of Black men, respectively, work in management and professional positions, the top job category in the United States (p. 277).

It is then possible that many of these financially successful Black women might be using the same concept of these White men by refusing to marry them to avoid any potential transfer of their wealth to these White men or non-Black men either through inheritance from death or from divorce. Also, Black women once had the experience of having children with White men who then left those children to the Black women to be

\footnotetext{
${ }^{18}$ Dwyer, Kelly. 2012. January 20. "Kobe Bryant loses all three (!) of his mansions, \$75 million, in divorce settlement," Yahoo News. Retrieved on May 1, 2012 from:

http://sports.yahoo.com/blogs/nba-ball-dont-lie/kobe-bryant-loses-three-man sions-75-million-divorce-184818486.html

${ }^{19}$ Kobe Bryant divorce: Wife Vanessa gets \$18.8 million in property,” 2012 , January 21. Los Angeles Times. Retrieved on May 16, 2012 from:

http://latimesblogs.latimes.com/lanow/2012/01/kobe-bryant-divorce-wife-va nessa-gets-188-million-in-property.html

${ }^{20}$ “Table 705. Money Income of People-Number by Income Level and by Sex, Race and Hispanics origin: 2009,” 2011. Statistical Abstract of the United States. U.S. Census Bureau. Retrieved on May 9, 2012 from: http://www.census.gov/compendia/statab/2012/tables/12s0705.pdf
} 
raised by themselves- "Fool me once, shame on you. Fool me twice, shame on me!” According to Jordan-Zachery (2007): "Evolutionary psychologists suggest that human mating strategies have evolved over the years, with women concentrating on men who are willing to and able to invest in their children. Men who fit this description are marriageable...” (pp. 85-86). According to Kaba (2008a), there were 73,523,000 children under 18 years old in the United States in 2005 , with $67.4 \%$ of them living with both parents; $23.4 \%$ of them living with their mother only; $4.7 \%$ living with their father only and $4.5 \%$ living with neither parent. For $10.1 \%$ of those living with their mother only, the mother as never married. For Black Americans, there were $11,295,000$ under 18 years old, with $35.1 \%$ of them living with both parents; $50.1 \%$ living with their mother only; $4.9 \%$ living with their father only; and $9.8 \%$ living with neither parent. For $32 \%$ of those living with their mother only, the mother has never married (p. 315).

\section{Religion/Religiosity}

Religion and Religiosity must not be ruled out as important factors as to why Black women turn down the romantic courtship requests from White men and other non-Black men in the United States. The high level of religiosity of Black females in the United States could also be a factor that leads some Black men not to seek romantic relationships with Black women because they are less religious than their female counterparts. In the United States, for Blacks and Whites, Religion is directly connected to politics, which in turn connects to residential segregation. Religion also is responsible for Black women in general to be different from all other groups including Black males when it comes to any number of human behaviors. Let us examine a number of examples to substantiate some of these claims. Most Black American females are very religious, attending religious services and religious activities more than any other groups or sub-group including Black males. In a January 30, 2009 report released by The Pew Forum, at least $87 \%$ of Black American women and $78 \%$ of Black American men in the United States were affiliated with Christian churches and that "African-American women also stand out for their high level of religious commitment. More than eight-in-ten black women (84\%) say religion is very important to them, and roughly six-in-ten (59\%) say they attend religious services at least once a week. No group of men or women from any other racial or ethnic background exhibits comparably high levels of religious observance" (Kaba, 2010: p. 114). For any man, Black, White or any other color who wants to be in a romantic relationship with a Black American woman, he must be ready to show some form of religiosity. For example, such a man must be willing to attend religious services regularly, contribute $10 \%$ of his earnings to a religious organization, and consume less or no alcohol or drugs since Black women in particular consume less or no alcohol or drugs compared with all other groups and sub-groups. For example, writing about women in prison in the United States, Belknap (2010) points out that the Black women were "... less likely to suffer from alcoholism..." (p. 1079). The Black American female mathematician, Iris Mack (2010) writes “... I was raised as a Christian Scientist

\footnotetext{
${ }^{21}$ Mack, Iris. 2010, April 29. "Bob Rubin Just Wants to Be Cuddled,” The Huffingtonpost.com. Retrieved on March 14, 2012 from: http://www.huffingtonpost.com/iris-mack/bob-rubin-just-wants-to-b_b_557 621.html?page=2)
}

and don't drink alcohol...,21 (also see Kaba, 2008a: pp. 327330).

Although the majority of Black Americans and Gentile European White Americans are not only Christians but more specifically Protestants, they tend to be divided politically. As a result, they worship separately on Sundays and other religious days, which leads them to live separate lives by residing in areas in very high proportions among themselves. This causes them not to have the opportunity to get to know one another and discuss issues that affect them all as human beings and Americans (Kaba, 2011e; Nealy, 2009). Kaba (2011e) points out that "Black Americans, including Black females are not only over $80 \%$ Christian, but the majority of them are also Protestant... The religion (Christianity) that Black and White Americans share, which was supposed to be the third major force to unite them has paradoxically turned out to divide them" (p. 189). According to Kosmin and Keysar (2009), in 2008, among non-Hispanic Whites in the United States, 21\% were Catholic, 15\% Baptists, 17\% Mainline Christians, 15\% Christian Generic, 3\% Pentecostal/Charismatic, 3\% Protestant Denominations and $16 \%$ said they belong to no religion. For non-Hispanic Blacks, 6\% were Catholics, 45\% Baptists, 7\% Mainline Christians, 15\% Christian Generic, 7\% Pentecostal/Charismatic, 6\% Protestant Denominations, and 11\% said they belong to no religion (p. 14).

According to Roland (1982): "The saying holds true that the hour from 11 to 12 on Sunday morning is the most segregated time of the week in the South" (pp. 10-11). According to Hadaway et al. (1984), the Church in general in the United States has been criticized for its lack of racial integration, especially that between Blacks and Whites and that "So much so, in fact, that 11 o'clock on Sunday morning has been called 'the most segregated hour in the United States'” (p. 204). Lawson (2007) presents many examples of Black Americans in the 1960s attempting to desegregate White churches in the South using a tactic known as "Kneel-Ins," where they would kneel in front of the churches. Among the cities in the South where these "Kneel Ins" protests took place are: Atlanta, Georgia, Birmingham, Alabama, Jackson, Mississippi, and Memphis, Tennessee. Roland (1982) explains this exclusion of Blacks from White churches by pointing out that: "If the southern white churches have sustained a sense of sectional independence, both they and the black churches have sustained a sense of racial independence. A British observer in the South during Reconstruction described the withdrawal of the blacks then occurring from the white churches as an extension of emancipation. It has remained thus to this day. The great majority of southern congregations are still completely black or white, or almost so, apparently by mutual consent” (p. 10).

Pertaining to residential segregation between Blacks and Whites in the United States, according to Charles (2003): "Blacks in 16 metropolitan areas were hyper-segregated from whites in 1980, exhibiting extreme isolation on at least four of five standard measures of residential distribution... In 29 US metropolitan areas - containing $40 \%$ of the total black population-blacks experienced 'extreme, multidimensional, and $\mathrm{cu}$ mulative residential segregation'” (pp. 170-171).

In terms of political affiliation and voting in national elections, while Blacks in general, and Black females in particular support or vote for the Democratic Party $90 \%$ of the time or more, the majority of European White Americans support or vote for the Republican Party. So during their Party Conven- 
tions, almost all Blacks are at the Democratic Party Convention, while very few to no Blacks, but a vast majority of European White Americans are at the Republican Party Convention (Kaba, 2011e). One can then deduce that for Black and White Americans, political differences lead to weak or lack of romantic relationships and marriage, or lack of romantic relationships and marriage lead to political divide.

In the United States, If European White American men become Democrats, they are more likely to be accepted by Black American women as romantic or marriage partners, just as Jewish American men have been accepted as romantic or marriage partners by Black women because they are Democrats (Kaba, 2008c: pp. 119-121). Religiously, Black American women and Jewish American men are connected or related through the Old Testament Bible and they are the center of attention in the stories of that part of the Holy Bible. So it is very common for each to visit the other's religious services, where they get to meet and know each other. This is in addition to also meeting regularly at thousands of Democratic Party meetings and conferences in states all across the vast United States all through the year to discuss the well-being of the party and the country before they meet again for the big Convention just before a presidential election.

For other non-Black men such as Asians, religion is also a factor as to why they may not be successful in their courtship of Black American women. This is because while the vast majority of Black American women are Christians, Asians in the United States may tend to be Buddhist, Hindu or Muslim.

\section{Conclusion}

This article began by presenting useful data illustrating that interracial romantic relationships, including marriage have increased substantially in the post 1960s era. The data illustrate that such relationships are a lot more common between Whites and Asians and Whites and Hispanics than between Whites and Blacks. This is especially the case with Black American women. The article then goes on to present as many examples as possible as to why so few White American men and other non-Black men engage in romantic relationships, including marriage with Black women in particular. Finally, the article attempts to present a counter argument that it is actually Black women in the United States who are turning down the courtship requests of White men and other non-Black men. Numerous examples are then presented to substantiate this claim, with any of those examples connected one way or the other to history, economics and the importance of gender as a variable.

\section{REFERENCES}

Alexander, M. (2010). The new Jim Crow: Mass incarceration in the age of colorblindness. New York: New Press.

Banks, R. R. (2011). Is marriage for white people? How the African American marriage decline affects everyone. New York: Dutton.

Belknap, J. (2010). “Offending wome”: A double entendre. Journal of Criminal Law \& Criminology, 100, 1061-1097.

Bernard, E. (2011). The marriage gap. Wilson Quarterly, 35, 88-90.

Blackmon, D. A. (2009). Slavery by another name: The re-enslavement of black Americans from the civil war to world war II. Harpswell, ME: Anchor.

Blau, P. M., Blum, T., Rytina, S., \& Schwartz, J. (1988). Inequality and intermarriage: A parado of motive and constraint. Social Forces, 66, 645-75. doi:10.1093/sf/66.3.645
Bobo, L. D. (2009). Crime, urban poverty, and social science. Du Bois Review, 6, 273-278. doi:10.1017/S1742058X0999021X

Bobo, L. D., \& Thompson, V. (2006). Unfair by design: The war on drugs, and the legitimacy of the criminal justice system. Social Research, 73, 445-472.

Boroughs, M. S., Krawczyk, R., \& Thompson, J. K. (2010). Body dysmorphic disorder among diverse race/ethnic and sexual orientation groups: Prevalence estimates and associated factors. Sex Roles, 63, 725-737. doi:10.1007/s11199-010-9831-1

Boroughs, M., Cafri, G., \& Thompson, J. K. (2005). Male body depilation: Prevalence and associated features of body hair removal. Sex Roles, 52, 638-644. doi:10.1007/s11199-005-3731-9

Boroughs, M., \& Thompson, J. K. (2002). Body depilation in males: A new body image concern? International Journal of Men's Health, 1, 247-257. doi:10.3149/jmh.0103.247

Brattain, M. (2005). Miscegenation and competing definitions of race in twentieth-century Louisiana. The Journal of Southern History, 71, 621-658. doi:10.2307/27648822

Brettschneider, M. (2010). Critical attention to race: Race segregation and Jewish Feminism. Bridges: A Jewish Feminist Journal, 15, 2033. doi:10.2979/BRI.2010.15.2.20

Charles, C. Z. (2003). The dynamics of racial residential segregation. Annual Review of Sociology, 29, 167-207. doi:10.1146/annurev.soc.29.010202.100002

Cocchiara, F., \& Bell, M. P. (2006). Latinas and black women: Key factors for a growing proportion of the US workforce. Equal Opportunities International, 25, 272-284. doi:10.1108/02610150610706258

Camp, S. M. H. (2000). Sally Hemings and Thomas Jefferson. The Mississippi Quarterly, 53, 275-283.

The Statistical Assessment Service (1997). Can intermarriage make you smarter and statistical assessment service, richer? http://www.stats.org/newsletters/9708/interrace2.htm

Carter, R. T., Pieterse, A. L., \& Smith III, S. (2008). Racial identity status profiles and expressions of anger in black Americans: An exploratory study. Journal of Multicultural Counseling and Development, 36, 101-112. doi:10.1002/j.2161-1912.2008.tb00074.x

Coleman, M. (1998). Homemaker as worker in the United States. Challenge, 41, 75-87.

Collins, J. (2003). "Poor and black and apt to stay that way”: Gambling on a sure thing in Louise Meriwether's daddy was a number runner. The Midwest Quarterly, 45, 49-58.

Cose, E. (2003). The black gender gap. Newsweek, 141, 46.

Cready, C. M., \& Saenz, R. (1997). The nonmetro/metro context of racial/ethnic outmarriage: Some differences between African Americans and Mexican Americans. Rural Sociology, 62, 335-362. doi:10.1111/j.1549-0831.1997.tb00655.x

Crenshaw, C. (1997). Resisting Whiteness' rhetorical silence. Western Journal of Communication, 61, 253-278. doi:10.1080/10570319709374577

Crowder, K. D., \& Tolnay, S. E. (2000). A new marriage squeeze for black women: The role of racial intermarriage by black men. Journal of Marriage and the Family, 62, 792-807. doi:10.1111/j.1741-3737.2000.00792.x

Degloma, T. (2009). Expanding trauma through space and time: Mapping the rhetorical strategies of trauma carrier groups. Social Psychology, 72, 105-122. doi:10.1177/019027250907200203

Drake, K. (1997). Rewriting the American self: Race, gender, and identity in the autobiographies of Frederick Douglass and Harriet Jacobs. Melus, 22, 91-108. doi:10.2307/467991

Du Bois, W. E. B. (1965). The souls of black folk. Three Negro Classics. New York: Avon Books.

Douglas, F. (2002). Narrative of the life of Frederick Douglas, An American slave. New York: Barnes \& Noble Books.

Edlund, L., \& Kopczuk, W. (2009). Women, wealth, and mobility. American Economic Review, 99, 146-178. doi:10.1257/aer.99.3.1082

Fears, D., \& Deane, C. (2001). Race, dating and marriage. Washington Post, A01.

Fenyo, M. D. (2001). Cross-cultural marriage; identity and choice. Journal of Third World Studies, 18, 334-335.

Fields, J., \& Casper, L. M. (2001). America's families and living ar- 
rangements 2000. US Census Bureau, Table FG3. P20-537. Washington DC: Government Printing Office. Table FG3 at:

http://www.census.gov/population/socdemo/hh-fam/p20-537/2000/ta bFG3.pdf

Firmin, M. W., \& Firebaugh, S. (2008). Historical analysis of college campus interracial dating. College Student Journal, 42, 782-788.

Fisher, C., \& Wiebe, C. (2003). Race, sex, and redemption in monster's ball. Ethnic Studies Review, 26, 68-80.

Foster, G. M. (2005). The great southern babylon: Sex, race, and respectability in New Orleans, 1865-1920. Journal of the History of Sexuality, 14, 219-223. doi:10.1353/sex.2006.0009

Fryer Jr., R. G. (2007). Guess who's been coming to dinner? Trends in interracial marriage over the 20th century. Journal of Economic Perspectives, 21, 71-90. doi:10.1257/jep.21.2.71

Gordon-Reed, A. (1998). Thomas Jefferson and Sally Hemings: An American controversy. Charlottesville, VA: University of Virginia Press.

Green, T. L., \& Darity Jr., W. A. (2010). Under the skin: Using theories from biology and the social sciences to explore the mechanisms behind the black-white health gap. American Journal of Public Health, 100, S36-S40. doi:10.2105/AJPH.2009.171140

Goss, L. (1997). Bessie Delany and Sadie Delany, with Amy Hill Hearth. Having our say: The delany sisters' first 100 years. AfroAmericans in New York Life and History, 21, 99-103.

Granger, D. (2002). Friendships between black and white women. The American Behavioral Scientist, 45, 1208-1213. doi:10.1177/0002764202045008004

Groves, C. P. (1989). Fauna of Australia. 44. Hominidae. In D. W. Walton, \& B. J. Richardson (Eds.), Fauna of australia volume 1B: Mammalia. Australian Biological Resources Study (ABRS). Collingwood: CSIRO Publishing.

Hama, A. (2010). The curse of ham: Race and slavery in early judaism, christianity and islam. Mankind Quarterly, 50, 174-177.

Hadaway, C. K., Hackett, D. G., \& Miller, J. F. (1984). The most segregated institution: Correlates of interracial church participation. Review of Religious Research, 25, 204-219. doi:10.2307/3511119

Harris-Perry, M. V. (2011). Sister citizen: Shame, stereotypes, and black women in America. New Haven, CT: Yale University Press.

Heep, H. (1995). The American body as a semiotic sign. The American Journal of Semiotics, 12, 261-272. doi:10.5840/ajs1995121/414

Henry, W. J. (2008). Black female Millennial College students: Dating dilemmas and identity development. Multicultural Education, 16, 1721.

High Beam Research (2003) Vital signs: Statistics that measure the state of racial inequality.

Hughes, Z. (2003a). Why some sisters only date whites \& “others". Ebony, 58, 55-58,70-74.

Hughes, Z. (2003b). Why some brothers only date whites and "others". Ebony, 58, 70-74.

Jacobs, M. D. (2002). The Eastmans and the Luhans; interracial marriage between white women and native American men, 1875-1935. Frontiers, 23, 29-54. doi:10.1353/fro.2003.0009

Jeter, K. (1982). Analytic essay: Intercultural and interracial marriage. Marriage and Family Review, 5, 105-111.

doi:10.1300/J002v05n01_10

Jin, W., Xu, S., Wang, H., Yu, Y., Shen, Y., Wu, B., \& Jin, L. (2011). "Genomeide detection of natural selection in African Americans preand post-admixture. Genome Research.

Jordan-Zachery, J. S. (2007). Policy interaction: The mixing of fatherhood, crime and urban policies. Journal of Social Policy, 37, 81-102.

Jones, A. (2010). “Stability of men's interracial first unions: A test of educational differentials and cohabitation history. Journal of Family and Economic Issues, 31, 241-256. doi:10.1007/s10834-010-9186-3

Jones, C., \& Shorter-Gooden, K. (2003). Shifting: The double lives of black women in America. New York: Harper Collins Publishers.

Joyner, K., \& Kao, G. (2000). School racial composition and adolescent racial Homophily. Social Science Quarterly, 81, 810.

Kaba, A. J. (2008a). Race, gender and progress: Are black American women the new model minority? Journal of African American Studies, 12, 309-335. doi:10.1007/s12111-008-9043-8

Kaba, A. J. (2008b). Sex ratio at birth and racial differences: Why do black women give birth to more females than non-black women? African Journal of Reproductive Health, 12, 139-150.

Kaba, A. J. (2008c). Review of race mixing: Black-white marriage in postwar America. The Journal of African American History, 93, 119121.

Kaba, A. J. (2010). Educational attainment, population increase and the progress of african americans. Journal of Pan African Studies, 3, 106-127.

Kaba, A. J. (2011a). Inter-ethnic/interracial romantic relationships in the United States: Factors responsible for the low rates of marriages between blacks and whites. Sociology Mind, 1, 121-129. doi:10.4236/sm.2011.13015

Kaba, A. J. (2011b). The family and political unity between blacks and Jews in the United States. International Journal of Humanities and Social Science, 1, 167-177.

Kaba, A. J. (2011c). Race, conquest and revenge: Why do black people resist racial revenge? International Journal of Humanities and Social Science, 1, 92-106.

Kaba, A. J. (2011d). Explaining the causes of the black-white wealth gap in the United States. Sociology Mind, 1, 138-143. doi:10.4236/sm.2011.13017

Kaba, A. J. (2011e). African American women voters: Review article. The Review of Black Political Economy, 38, 183-203. doi:10.1007/s12114-011-9092-4

Kaba, A. J. (2012a). The exclusion of black women from national leadership positions in the United States: Taxation with Limited representation. Sociology Mind, 2, 133-140. doi:10.4236/sm.2012.22017

Kaba, A. J. (2012b). Talented tenth: An analysis of the 2011 root magazine's 100 most influential young black Americans. International Journal of Humanities and Social Science, 2, 1-31.

Kaba, A. J. (2012c). African Americans in the US women's national basketball association, 2006: From the NCAA to the WNBA. Sociology Mind, 2, 95-108. doi:10.4236/sm.2012.21013

Kalmijn, M. (1998). Intermarriage and homogamy: Causes, patterns, trends. Annual Review of Sociology, 24, 395-421. doi:10.1146/annurev.soc.24.1.395

Kalmijn, M. (1993). Trends in black/white intermarriage. Social Forces, 72, 119-146. doi:10.2307/2580162

Kennedy, R. (2002). Interracial intimacy. The Atlantic Monthly. URL (last checked 4 May 2012).

http://www.theatlantic.com/past/docs/issues/2002/12/kennedy.htm

Kitwana, B. (2002). The hip hop generation: The crisis in African American culture. New York: Basic Civitas Books.

Kosmin, B. A., \& Keysar, A. (2009). American Religious Identification Survey (ARIS 2008). URL (last checked 10 April 2009). http://www.americanreligionsurvey-aris.org/reports/ARIS_Report_2 008.pdf

Lawson, C. (2007). The most segregated hour in America: Protesting segregation in the church. URL (last checked 2 April 2009). http://dam.rhodes.edu;8080/dspace/handle/10267/2420

Leslie, A. R. (1996). Multiracial couples. Journal of Marriage and the Family, 58, 530-531. doi:10.2307/353519

Lewis, D. L. (1993). W. E. B. DuBois: Biography of a race. 1868-1919. New York: John Macrae Book, Henry Holt and Company, Inc.

Lichter, D. T., LeClere, F. B., \& McLaughlin, D. K. (1991). Local marriage markets and the marital behavior of black and white women. The American Journal of Sociology, 96, 843-867. doi:10.1086/229610

Malherbe, V. C. (2006). Illegitimacy and family formation in colonial Cape Town, to c. 1850. Journal of Social History, 39, 1153-1176. doi:10.1353/jsh.2006.0047

Manning, W. D., \& Smock, P. J. (1995). Why marry? Race and the transition to marriage among cohabitors. Demography, 32, 509-520. doi: $10.2307 / 2061671$

Mare, R. D. (1991). Five decades of educational assortative mating. American Sociological Review, 56, 15-32. doi:10.2307/2095670

McClain, C. S. (2004). Black by choice: Identity preferences of Americans of black/white parentage. The Black Scholar, 34, 43-54.

McClintock, E. A. (2010). When does race matter? Race, sex, and dating at an elite university. Journal of Marriage and Family, 72, 
45-72. doi:10.1111/j.1741-3737.2009.00683.x

McCreary, D. R., Hildebrandt, T. B., Heinberg, L. J., Boroughs, M., \& Thompson, J. K. (2007). A review of body image influences on men's fitness goals and supplement use. American Journal of Men's Health, 1, 307-316. doi:10.1177/1557988306309408

McWhorter, J. (2003). Authentically black. Essays for the black silent majority. New York: Gotham Books.

Mills, C., Green, M., \& Lawson, S. (1999). Black women speak out... about their interracial relationship. Interrace, 45, 4.

Millward, J. (2010). “The relics of slavery”: Interracial sex and manumission in the American South. Frontiers, 31, 22-30.

Mitchell, A. (2001). Not enough of the past: Feminist revisions of slavery in Octavia E. Butler's kindred. Melus, 26, 51-75. doi: $10.2307 / 3185557$

Mitchell, M. N. (2006). Righteous propagation: African Americans and the politics of racial destiny after reconstruction. The Journal of Southern History, 72, 688-690. doi:10.2307/27649192

Model, S., \& Fisher, G. (2001). Black-white unions: West Indians and African Americans compared. Demography, 38, 177-185. doi:10.1353/dem.2001.0019

Morgan, M., \& Bennett, D. (2006). Getting off of black women's backs: Love her or leave her alone. Du Bois Review, 3, 485-502. doi:10.1017/S1742058X06060334

Nealy, L. N. (2009). African American women voters: Racializing religiosity, political consciousness and progressive political action in US presidential elections from 1964 through 2008. Lanhan: University Press of America.

Newman, A. A. (2010). No body hair left behind. New York Times, E6.

O’Brien, C. C. (2006). What the Dickens?: Intertextual influence and the inheritance of virtue in Julia C. Collins's The Curse of Caste; or The Slave Bride. African American Review, 40, 661-685.

O’Brien, C. C. (2003). Racing toward civilization: Sexual slavery and nativism in the novels of Pauline Elizabeth Hopkins and Alice Wellington Rollins. Legacy, 20, 118-133. doi:10.1353/leg.2003.0059

Oakley, S. (2007). The libertine colony: Creolization in the Early French Caribbean. Wadabagei: A Journal of the Caribbean and Its Diaspora, 10, 104-109.

Oliver, J. E., \& Wong, J. (2003). Intergroup prejudice in multiethnic settings. American Journal of Political Science, 47, 567-582. doi:10.1111/1540-5907.00040

Ondaatje, C. (1998). Journey to the source of the nile. New York: Harper Collins Publishers Ltd.

Perry, B., \& Sutton, M. (2008). Policing the colour line violence against those in intimate interracial relationships. Race, Gender \& Class, 15, 240-261.

Philpot, T. S., \& Walton Jr., H. (2007). One of our own: Black female candidates and the voters who support them. American Journal of Political Science, 51, 49-62. doi:10.1111/j.1540-5907.2007.00236.x

Pittman, C. (2007). Black women writers and the trouble with ethos: Harriet Jacobs, Billie Holiday, and Sister Souljah. Rhetoric Society Quarterly, 37, 43-70. doi:10.1080/02773940600860074

Porter, M. M., \& Bronzaft, A. L. (1995). Do the future plans of educated black women include black mates. The Journal of Negro Education, 64, 162-170. doi:10.2307/2967239

Qian, Z. (1997). Breaking the racial barriers: Variations in interracial marriage between 1980 and 1990. Demography, 34, 263-276. doi:10.2307/2061704

Robnett, B., \& Feliciano, C. (2011). Patterns of racial-ethnic exclusion by internet daters. Social Forces, 89, 807-828. doi:10.1353/sof.2011.0008

Roland, C. P. (1982). The ever-vanishing South. Journal of Southern History, 48, 3-20. doi:10.2307/2207294

Rogers, J. A. (1952). Nature knows no color-line (3rd ed.). St. Petersburg, FL: Helga M. Rogers.

Rogers, J. A. (1944). Sex and race vol. III. St. Petersburg, FL: Helga M. Rogers.

Romano, R. C. (2006). Race mixing: Black-white marriage in postwar America. Gainesville, FL: University Press of Florida.

Saint Louis, C. (2009). Do women like men quite that clean shaven?
New York Times, E3.

Scanlon, M. (1998). The divine body in Grace Nichols’s The Fat Black Woman's Poems. World Literature, 72, 59-66. doi: $10.2307 / 40153535$

Simmons, C. (2003). Women's power in sex radical challenges to marriage in the early-twentieth-century. Feminist Studies, 29, 168198.

Sivanarayanan, A. (2005). The black female body: A photographic history. Callaloo, 28, 1108-1113. doi:10.1353/cal.2006.0036

Soomer, J. (2000). The manipulation of the production and reproduction of African women in the caribbean during slavery. Negro History Review, 63, 1-7.

Sowell, T. (1978). Essays and data on American ethnic groups. Washington DC: The Urban Institute Press.

Storrs, D. (1997). Multiracial couples: Black and white voices. Journal of Comparative Family Studies, 28, 325-327.

Strub, W. (2007). Black and white and banned all over: Race, censorship and obscenity in postwar Memphis. Journal of Social History, 40, 685-715. doi:10.1353/jsh.2007.0072

Taslitz, A. E. (2009). Judging Jena's D.A.: The prosecutor and racial esteem. Harvard Civil Rights, 44, 393-459.

Tobin, D. J. (2006). The genetically programmed hair growth cycle and alopecia: What is there to know? Expert Review of Dermatology, 1, 414-427. doi:10.1586/17469872.1.3.413

Toldson, I. A., \& Marks, B. (2011). New research shatters myths and provides new hope for black love and marriage. URL (last checked 20 March 2012).

http://www.empowernewsmag.com/listings.php?article=2051

Tucker, M. B., \& Mitchell-Kernan, C. (1990). New trends in black american interracial marriage: The social structural context. Journal of Marriage and the Family, 52, 209-218. doi:10.2307/352851

US Census Bureau (1999). Interracial married couples: 1960 to present. Washington DC: Government Printing Office.

US Department of Education (2012). Revealing new truths about our nation's school. URL (last checked 9 March 2012).

http://www2.ed.gov/about/offices/list/ocr/docs/crdc-2012-data-summ ary.pdf

Walsh, E. T. (2012). How “commonsense” notions of race, class and gender infiltrate families formed across the color line. Sociology Mind, 2, 75-79. doi:10.4236/sm.2012.21010

Washington, E. (2006). How black candidates affect voter turnout. Quarterly Journal of Economics, 121, 973-998. doi:10.1162/qjec.121.3.973

Washington-Williams, E. M., \& Stadiem, W. (2005). Dear senator: A memoir by the daughter of strom thurmond. New York: Regan Books.

Wickham, D. (2002). Bill clinton and black America. New York: Ballantine Books.

Wilensky, J. (2002). Relationships. Human Ecology, 30, 16-18.

Williams, A. W. (2003). Our collective responsibility to black males. Black Issues in Higher Education, 20, 19.

Williams, M. E. (2009). “Meet the real lena horne”: Representations of lena horne in ebony magazine, 1945-1949. Journal of American Studies, 43, 117-130. doi:10.1017/S0021875809006094

Wilson, W. J. (1987). The truly disadvantaged. Chicago: University of Chicago Press.

Wong, L. Y. (2003). Why do only 5.5\% of black men marry white women. International Economic Review, 44, 803-826. doi:10.1111/1468-2354.t01-1-00090

Wright, J. W. (2004). The New York Times Almanac. New York: Penguin Group.

Yancey, G. A., \& Yancey, S. W. (1997). Black-white differences in the use of personal advertisements for individuals seeking interracial relationships. Journal of Black Studies, 27, 650-667.

Yarbrough, F. A. (2005). Power perception, and interracial sex: Former slaves recall a multiracial south. The Journal of Southern History, 71, 559-588. doi:10.2307/27648820

Zernike, K. (2004). Sizing up America: Signs of expansion from head to toe. New York Times, A.1. 